OPEN ACCESS

Edited by:

Gestur Vidarsson

Sanquin Research, Netherlands

Reviewed by:

Marc Daëron,

Institut Pasteur, France

Peter Sun,

National Institute of Allergy and Infectious Diseases, United States

*Correspondence:

P. Mark Hogarth

mark.hogarth@burnet.edu.au

Specialty section:

This article was submitted to

Molecular Innate Immunity,

a section of the journal

Frontiers in Immunology

Received: 20 December 2018

Accepted: 21 February 2019

Published: 19 March 2019

Citation:

Anania JC, Chenoweth AM, Wines BD and Hogarth PM (2019) The Human FcyRll (CD32) Family of Leukocyte

FCR in Health and Disease.

Front. Immunol. 10:464

doi: 10.3389/fimmu.2019.00464

\section{The Human Fc $\gamma$ RII (CD32) Family of Leukocyte FcR in Health and Disease}

\author{
Jessica C. Anania ${ }^{1,2}$, Alicia M. Chenoweth ${ }^{1,2}$, Bruce D. Wines ${ }^{1,2,3}$ and P. Mark Hogarth ${ }^{1,2,3 *}$ \\ ${ }^{1}$ Centre for Biomedical Research, Burnet Institute, Melbourne, VIC, Australia, ${ }^{2}$ Department of Immunology and Pathology, \\ Central Clinical School, Monash University, Melbourne, VIC, Australia, ${ }^{3}$ Department of Pathology, The University of \\ Melbourne, Melbourne, VIC, Australia
}

Fc $\gamma$ Rs have been the focus of extensive research due to their key role linking innate and humoral immunity and their implication in both inflammatory and infectious disease. Within the human Fc $\gamma R$ family FcyRll (activatory FcyRlla and Fc $\gamma R$ Illc, and inhibitory Fc $\gamma R$ Rllb) are unique in their ability to signal independent of the common $\gamma$ chain. Through improved understanding of the structure of these receptors and how this affects their function we may be able to better understand how to target FcyR specific immune activation or inhibition, which will facilitate in the development of therapeutic monoclonal antibodies in patients where Fc $\gamma$ RII activity may be desirable for efficacy. This review is focused on roles of the human Fc $\gamma \mathrm{R}$ Il family members and their link to immunoregulation in healthy individuals and infection, autoimmunity and cancer.

Keywords: Fc receptor, Fc $\gamma R$, inflammation, infection, autoimmunity, cancer, mAb therapeutics

\section{INTRODUCTION}

Fc receptors are, by definition, receptors for the Fc portion of immunoglobulins (Ig). These have been traditionally viewed primarily as cell surface receptors for Ig and whose interaction drives a surprisingly diverse range of responses mostly within the immune system or related to the physiology of antibodies in immunity.

Receptors for IgM, IgA, IgG, and IgE have been defined over the last 40 years with the majority of research focused on the receptors found on leukocytes. These receptors induce or regulate leukocyte effector functions during the course of immune responses. It is noteworthy, and also beyond the scope of this review, that a limited number and type of Fc receptors are also expressed on cells outside the immune system where they affect or participate in physiology of antibody function.

In humans, the largest grouping of Fc receptors is the "leukocyte Fc receptors" expressed primarily on effector cells. Their ectodomains bind ligand, the IgG antibody Fc region, and belong to the Ig-superfamily. They include the high affinity IgE receptor FceRI and the distantly related IgA receptor Fc $\alpha$ RI, but the largest group are the IgG receptors or the $\mathrm{F} c \gamma \mathrm{Rs}$ which themselves comprise several groups-Fc $\gamma$ RI, the high affinity IgG receptor, the Fc $\gamma$ RII family (Fc $\gamma$ RIIA, Fc $\gamma$ RIIB, Fc $\gamma$ RIIC), and the Fc $\gamma$ RIII family $(1,2)$.

\section{THE HUMAN Fc $\gamma$ RII (CD32) FAMILY OF LEUKOCYTE FCR \\ General Comments}

The human Fc $\gamma$ RII family (also known as CD32 in the Cluster of Differentiation nomenclature) consists of a family of primarily cell membrane receptor proteins. They are encoded by the mRNA splice variants of three highly related genes-FCGR2A, FCGR2B, and FCGR2C, which arose by recombination of the FCGR2A and FCGR2B genes (3). 
All members of the Fc $\gamma$ RII family are integral membrane glycoproteins and contain conserved extracellular domains, exhibiting an overall $85 \%$ amino acid identity $(3,4)$. The high degree of amino acid and DNA identity has posed challenges in the analysis of receptor function using monoclonal antibody or nucleic acid based methods. Thus, some caution should be exercised when analyzing literature or interpreting experimental data. The encoded products of the three genes are low-affinity receptors that are defined practically as interacting poorly with monomeric IgG, i.e., micromolar affinity $(5,6)$, but when arrayed on the cell surface, they avidly bind multivalent complexes of IgG, e.g., immune complexes.

The Fc $\gamma$ RIIA (also Fc $\gamma$ RIIC) and Fc $\gamma$ RIIB proteins have opposing cellular functions. Fc $\gamma$ RIIA proteins are activating-type Fc receptors. In contrast, Fc $\gamma$ RIIB is a key immune checkpoint that modulates the action of activating-type $F c$ receptors and the antigen receptor of B cells. When expressed, the Fc $\gamma$ RIIC proteins retain the activating function of the cytoplasmic tail of Fc $\gamma$ RIIA and the binding specificity of Fc $\gamma$ RIIB ectodomains.

The focus of this review is the FcyRII family and their actions as receptors for immunoglobulins. It should be noted that Fc $\gamma$ RIIA also acts as a receptor for pentraxins, a product of innate immunity that is important in infection and inflammation and which has been recently reviewed elsewhere (7). Since much of the biology of the Fc receptors has been determined in the mouse, it is noteworthy that the human and mouse FcR families differ significantly, with Fc $\gamma$ RIIB being the only Fc $\gamma$ RII forms in the mouse. Also, although the human and mouse Fc $\gamma$ RIIB homologs are highly conserved, there are differences in their splice variants in the two species (see below). Importantly, cellular expression can also vary between humans and mice.

Human Fc $\gamma$ RII gene polymorphism, mRNA splicing, and copy number variation (CNV) further diversifies the potential biological consequences of IgG interactions with the Fc $\gamma$ RII receptor proteins. These properties and roles of each group of $\mathrm{Fc} \gamma \mathrm{RII}$ proteins are reviewed in detail in the following sections.

\section{PROPERTIES OF Fc $\gamma$ RIIA}

\section{Molecular Structure}

The human Fc $\gamma$ RIIA proteins were originally defined by crossspecies gene cloning (8). They are encoded by the FCGR2A gene (Figure 1) and are comprised of eight exons; two encoding the 5 ' UTR, and leader sequence and the $\mathrm{N}$-terminus of the mature protein; one exon for each of the two Ig-like domains of the extracellular region; one exon for the transmembrane domain; and three exons encoding the cytoplasmic tail and $3^{\prime}$ UTR (3). Three mRNA transcripts, two of which encode membrane proteins, arise by alternative splicing of the mRNA (Figure 1).

The most extensively characterized form is the canonical 40 $\mathrm{kDa}$ integral membrane protein, Fc $\gamma$ RIIA1, that contains all but the first $\left(\mathrm{Cl}^{*}\right)$ cytoplasmic sequence $(3,4,8-10)$. A second, but relatively rare, membrane form has been recently described $(11,12)$. Fc $\gamma$ RIIA3 is identical in sequence to the canonical Fc $\gamma$ RIIA1, with the notable exception of a 19-amino acid insert in its cytoplasmic tail, arising from the inclusion of the $\mathrm{C} 1^{*}$ exon which was believed previously to be a vestigial or cryptic exon (4).
This insertion is highly homologous (18/19-amino acids) to the insertion present in the cytoplasmic tail of inhibitory Fc $\gamma$ RIIB1 (11-13). mRNA splicing that successfully gives rise to Fc $\gamma$ RIIA3 is associated with an FCGR2 $A^{\text {c.7421871A }>\text { G }}$ SNP that creates a splice acceptor site, which greatly increases the inclusion of the C1* exon (11).

An unusual mRNA has been reported that lacks the transmembrane exon resulting in a potentially secreted 32 $\mathrm{kDa}$ polypeptide (14). This Fc $\gamma$ RIIA2 form is not extensively characterized and its physiology is uncertain. However, it raises the possibility that naturally occurring soluble forms may act as modulators of immune complex-induced activation and inflammation and it is noteworthy that recombinant soluble Fc $\gamma$ RIIA inhibits immune complex-induced activation of inflammatory cells in vitro and in vivo (9).

\section{Cellular Expression}

The Fc $\gamma$ RIIA proteins are unique to primates $(15,16)$. Fc $\gamma$ RIIA1 is the most widespread and abundant of all $\mathrm{Fc} \gamma \mathrm{R}$, present on Langerhans cells, platelets and all leukocytes, with the exception of most lymphocytes (Table 1) $(1,16,17)$. Fc $\gamma$ RIIA3 is expressed by neutrophils and monocytes (11) and Fc $\gamma$ RIIA2 mRNA is present in platelets, megakaryocytes, and Langerhans cells (14). The levels of Fc $\gamma$ RIIA expression are influenced by cytokine exposure. Interferon (IFN) $-\gamma$, interleukin (IL)-3, IL-6, IFN- $\gamma$, C5a, prostaglandin-E (PGE), and dexamethasone increase expression, but IL-4, tumor necrosis factor (TNF)- $\alpha$, and TNF- $\beta$ reduce expression (18-21). There are also reports of Fc $\gamma$ RII induction on CD4 and CD8 T cells upon mitogen or TCR stimulation. Both Fc $\gamma$ RIIA and Fc $\gamma$ RIIB are reported to be expressed on activated CD4 T cells $(22,23)$.

\section{Fc $\gamma$ RIIA Signaling ITAM Activation vs. ITAM Inhibition}

Like other activating-type immunoreceptors, Fc $\gamma$ RIIA and Fc $\gamma$ RIIC signal via the Immunoreceptor Tyrosine-based Activation Motif (ITAM) pathway (24-26) with a major structural difference. In the case of all other activating-type immunoreceptors-which includes the antigen receptors as well as the activating type FcR, e.g., FceRI, FcyRIIIA-the ligand binding chain and the signaling subunits are encoded in separate polypeptides e.g., Fc $\gamma$ RIIIA and the common FcR- $\gamma$ chain dimer. The assembly of a functional signaling complex requires their non-covalent association (17). However, in the case of Fc $\gamma$ RIIA and Fc $\gamma$ RIIC, the ITAM is present in its own IgG binding chain. Furthermore, the Fc $\gamma$ RIIA ITAM is unusual in that it does not fit the canonical ITAM consensus sequence and includes three additional aspartic residues (Table 2), although how this affects Fc $\gamma$ RII function remains unknown (13). ITAM signaling is essential for Fc $\gamma$ RIIA-dependent phagocytosis and the induction of cytokine secretion induced by its aggregation by immune complexes. Such high stoichiometry aggregation of receptors results in receptor-associated src family kinase, particularly Fyn (27), mediated phosphorylation of the two tyrosines of the ITAM and the recruitment of Syk and the propagation of activatory signaling pathways. In human Fc $\gamma$ RIIA transgenic mice, Fyn deficiency is protective in models of $F c \gamma R$ dependent nephritis 


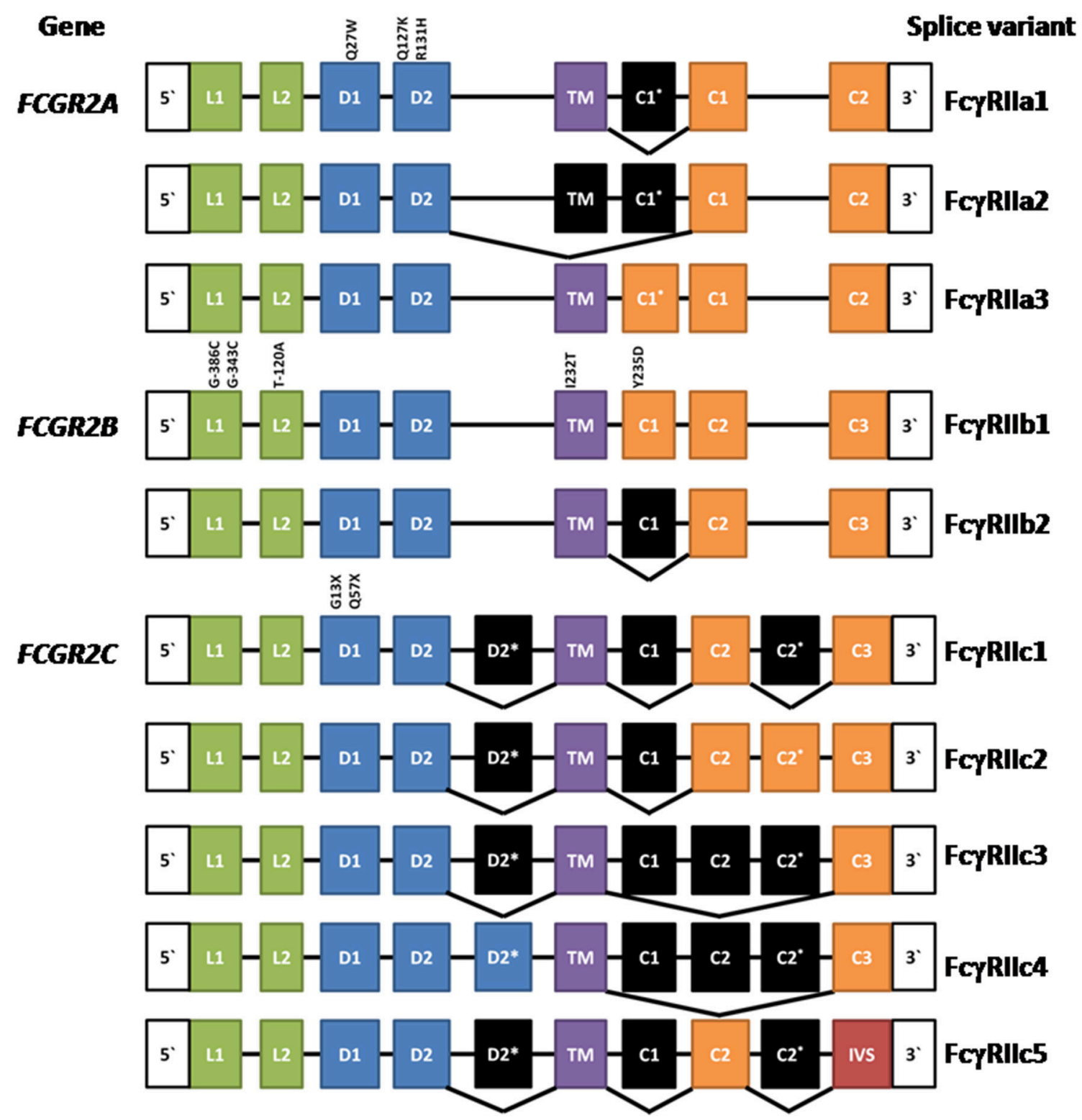

FIGURE 1 | Composition of FCGR2A, FCGR2B, and FCGR2C and their splice variants. Leader (L), ectodomain (D), transmembrane (TM) cytoplasmic tail (c), and intervening sequence (IVS). Expressed exons are illustrated in color, while spliced exons (selectively expressed) are represented in black. The location and position number of amino acids affected by well characterized polymorphisms are shown above the exons except for the FCGR2B leader exons where the nucleotide positions are given. See text for references.

and arthritis, indicating a pivotal pro-inflammatory role for Fyn kinase in ITAM signaling (27).

Since the original characterization of the activating role of ITAM pathway was described, it is now apparent that ITAMs can under certain circumstances mediate inhibitory or modulating function termed ITAMi (inhibitory ITAM) $(28,29)$. Under conditions of low stoichiometric interaction, the receptorassociated src family kinase Lyn phosphorylates only one of the two tyrosine residues (mono-tyrosine phosphorylation) within the ITAM, with two juxtaposed receptors presenting
mono-phosphylated-ITAMs to recruit the two SH2 domains of the SH2-domain containing protein tyrosine phosphatase 1 (SHP-1). This interaction is not dissimilar to SHP1 binding via its dual $\mathrm{SH} 2$ domains to inhibitory immunoreceptors with dual ITIMs (30). Then Lyn phosphorylation of $\mathrm{Tyr}^{536}$ of SHP1 positively regulates SHP-1 phosphatase activity resulting in the inhibition of cell activation (27). Animal studies suggest that the ITAMi effect ameliorates pathological inflammatory responses and may also be important in controlling "baseline" receptor activation. This ITAMi effect is not unique to the unusual 
TABLE 1 | Leukocyte Expression of FcyRll forms.

\begin{tabular}{llll}
\hline Cell type & Fc $\gamma$ RIIA & Fc $\gamma$ RIIB & Fc $\gamma$ RIIC \\
\hline T cells & $\mathrm{j}^{\mathrm{b}}$ & $\mathrm{j}$ & $?$ \\
B cells & - & +++ & + \\
NK cells & - & $-{ }^{\mathrm{c}}$ & + \\
Macrophages & +++ & ++ & $?$ \\
Monocytes & +++ & + & $?$ \\
Neutrophils & +++ & + & $?$ \\
Eosinophils & ++ & - & - \\
Basophils & ++ & +++ & - \\
Mast cells & ++ & $-\mathrm{d}$ & - \\
Platelets & ++ & - & - \\
\hline
\end{tabular}

+++ High, ++ Moderate, + Low, or - No expression. • no data.

a Expressed only in $20 \%$ of humans;

${ }^{b}$ Expression induced in some $T$ cell subpopulations;

${ }^{c}$ Expressed as a result of promoter modification related to FC $\gamma R$ RIIC allelism.

${ }^{d}$ Conflicting results.

TABLE 2 | Sequence comparison of ITAMs of activating type Fc $\gamma R$.

\begin{tabular}{ll}
\hline Receptor ITAM & Consensus $^{\mathbf{a}}$ \\
\hline FCR- $\gamma$ chain & YTGL STRN---QET YETL \\
FC $\gamma R \| A$ and FC $\gamma \| C$ & YMTL NPRAPTDDDKNI YLTL
\end{tabular}

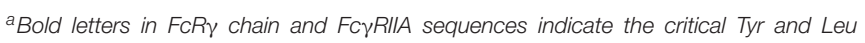
residues of the ITAM consensus motif $Y X x L / I(6-12) Y X x L$.

Fc $\gamma$ RIIA ITAM (29) as it has been also described for Fc $\alpha$ RI $(31,32)$ and Fc $\gamma$ RIIIA (33), both of which signal through the common FcR- $\gamma$ chain dimer which contains canonical ITAMs.

\section{Cellular Responses}

Fc $\gamma$ RIIA aggregation by IgG cross-linking initiates a variety of effector responses, depending on cellular expression which is affected by the local cytokine environment, and cross-talk between other FcR and TLR $(34,35)$. Internalization via both endocytosis and phagocytosis can be mediated by Fc $\gamma$ RIIA in cell lines, i.e., ts20 (36, 37), COS-1 (38), U937 (39) as well as in primary human cells i.e., neutrophils $(40,41)$, monocytes (40), platelets (40, 42), and macrophages (43). Fc $\gamma \mathrm{R}$ phagocytosis requires ITAM activation, which also initiates the ubiquitin conjugation system. Conversely, endocytosis is dependent only on ubiquitination and clathrin, not ITAM phosphorylation $(36,37)$.

The internalization of antigen: antibody immune complexes by Fc $\gamma \mathrm{R}$ on antigen presenting cells (especially dendritic cells) is an important part of antigen presentation for the development of effective immune responses. This process also increases the efficiency of $\mathrm{T}$ cell activation particularly in response to low concentrations of antigen (44). The role of human $\mathrm{Fc} \gamma \mathrm{R}$ in antigen presentation is well documented in in vitro systems and it appears that all Fc $\gamma \mathrm{R}$ are important at some level (4547). However, more recent analyses have shown Fc $\gamma$ RIIA is the major receptor in the development of so-called "vaccinal effects" of monoclonal antibody therapy in cancer. It appears that the therapeutic antibodies targeting cancer cells can induce a long lasting protective response beyond the acute therapeutic phase of the therapy (48).

Fc $\gamma$ RIIA1 activates neutrophils and other myeloid effector cells for direct killing of IgG-opsonized target cells including tumor cells and virus-infected cells (49). Also, Fc $\gamma$ RIIA binding of IgG immune complexes triggers granulocytes to release inflammatory mediators such as prostaglandins, lysosomal enzymes, and reactive oxygen species, as well as cytokines including IFN $\gamma, \mathrm{TNF} \alpha$, IL-1, and IL-6 $(50,51)$. The Fc $\gamma$ RIIA3 splice variant form is an even more potent activator of human neutrophils than Fc $\gamma$ RIIA1, and is responsible for some severe adverse reactions to immunoglobulin replacement therapy (11). The mechanistic basis of this potency relates to its longer retention time in the cell membrane and the consequential enhanced ITAM signaling (12). Whilst this enhanced potency may present a risk factor for hypersensitivity to immunoglobulin replacement therapy, it may provide some benefit for protection against infection.

The limited number of studies of FcyRII expression of human T cells suggest Fc $\gamma$ RII crosslinking on TCR-stimulated $\mathrm{CD} 4 \mathrm{~T}$ cells enhances proliferation and cytokine secretion, suggesting an activating function of $\operatorname{Fc} \gamma \operatorname{RIIA}(22,23)$. The nature of FcyRIIA expression on CD4 T cells is not straightforward nor completely characterized. Purified CD4 T cells when stimulated with anti-CD3/CD28 induced surface expression of Fc $\gamma$ RII on $10 \%$ of cells and intracellular expression in $50 \%$. In contrast, unstimulated cells express little Fc $\gamma$ RII (23). Imaging of Fc $\gamma$ RII-expressing CD4 T cells sorted from unstimulated normal peripheral blood mononuclear cells, or those from $\mathrm{HIV}-1^{+}$ individuals shows cells displaying punctate Fc $\gamma$ RIIA staining (23) or discrete patches of B cell membrane. These B cell membrane patches include Fc $\gamma$ RIIB and CD19 markers (52), consistent with possible trogocytosis by the activated $\mathrm{T}$ cell from the $\mathrm{B}$ cell. Similarly, FcyRIIIA is also expressed on activated CD4 T cells, and this expression appears to be both intrinsic upon cell activation and acquired by trogocytosis of APC membrane (53).

Fc $\gamma$ RIIA plays an important role in the normal physiology of platelet activation, adhesion, and aggregation following vessel injury (54). More recent studies indicate Fc $\gamma$ RIIA associates with glycoprotein (GP) Ib-IX-V on platelets and can thereby be indirectly stimulated by von Willebrand factor (VWF) or after stimulation of G-protein-coupled receptors (GPCRs) (54). Interestingly, Fc $\gamma$ RIIA signaling on platelets is regulated by proteolytic cleavage of the cytoplasmic tail, or "de-ITAM-ising" (55).

\section{PROPERTIES OF Fc $\gamma$ RIIB}

\section{Molecular Structure}

Initially, Fc $\gamma$ RIIB was discovered in the mouse by protein sequence and molecular cloning analyses $(56,57)$ and the human FCGR2B gene was then isolated by cross species hybridization. Human FCGR2B has similar structure to human FCGR2A, being comprised of eight exons. The two major forms of Fc $\gamma$ RIIBFc $\gamma$ RIIB1 and Fc $\gamma$ RIIB2 (Figure 1) - arise from mRNA splicing 
which results in the inclusion or exclusion of the $\mathrm{C} 1$ exon sequence in Fc $\gamma$ RIIB1 and Fc $\gamma$ RIIB2 isoforms, respectively $(3,4)$. The inclusion of the $\mathrm{C} 1$ exon sequence in the Fc $\gamma$ RIIB1 results in tethering to the membrane of $\mathrm{B}$ cells, whereas its absence from Fc $\gamma$ RIIB2 allows rapid internalization of the receptor in myeloid cells. Both forms contain the Immunoreceptor Tyrosinebased Inhibitory Motif (ITIM) in their cytoplasmic tails. The extracellular domains are $95 \%$ identical to the two domains of Fc $\gamma$ RIIA and almost completely identical to the Fc $\gamma$ RIIC $(3,8,17)$. Although the focus of this review is the human Fc $\gamma$ RII, it should be noted that mouse Fc $\gamma$ RIIB comprises three splice variants Fc $\gamma$ RIIB1, Fc $\gamma$ RIIB1', and Fc $\gamma$ RIIB2, with the predicated amino acid sequences of the latter two corresponding to the human Fc $\gamma$ RIIB1 and Fc $\gamma$ RIIB2 variants. Any functional differences between the two mouse Fc $\gamma$ RIIB1 and Fc $\gamma$ RIIB1' forms are unknown (58). There are also amino acid sequence differences between human Fc $\gamma$ RIIB1 and mouse Fc $\gamma$ RIIB1/1' and the functional consequences of these are also unknown.

\section{Cellular Expression}

As indicated in "General Comments" above, the analysis of expression of human Fc $\gamma$ RIIB protein has been historically difficult because of the extremely high sequence conservation of the extracellular domains of Fc $\gamma$ RIIB, Fc $\gamma$ RIIA, and Fc $\gamma$ RIIC and lack of specific monoclonal antibody probes. The high degree of DNA sequence conservation has also confounded analysis. Much of the early literature has relied on either PCRs or interpretation of data using antibodies that are cross-reactive with, or specific for, Fc $\gamma$ RIIA or a combination of these methods and reagents. The relatively recent development of such Fc $\gamma$ RIIA/C and Fc $\gamma$ RIIB specific antibodies (59-61) has now helped to clarify expression patterns, but there are still differences reported between groups using these reagents. Some caution should still be exercised in analysis of the historic literature. Furthermore, cell expression patterns of Fc $\gamma$ RIIB in mouse myeloid derived cells is substantially different to human Fc $\gamma$ RIIB, thus additional caution is advised in interpreting the data. Nonetheless, it is clear that Fc $\gamma$ RIIB (Fc $\gamma$ RIIB1) is highly expressed by B cells, and its mRNA has also been identified at lower levels on monocytes (Table 1) (62). The levels of Fc $\gamma$ RIIB expression are influenced by cytokine exposure. Cytokines such as IL-10, IL-6, and dexamethasone increase expression of Fc $\gamma$ RIIB, while TNF- $\alpha$, C5a and IFN- $\gamma$ inhibit expression (18-20).

Fc $\gamma$ RIIB (Fc $\gamma$ RIIB2) is highly expressed on basophils and at low levels on monocytes (63). Expression on other granulocytes is somewhat complex and controversial. The differences in reported expression of Fc $\gamma$ RIIB on mast cells may reflect technological limitations or differences in tissue origin of the cells under investigation. Intestinal and cord blood derived mast cells have been reported as expressing Fc $\gamma$ RIIB on the basis of mRNA expression (64). In one study using human leukocyte reconstituted mice and a Fc $\gamma$ RIIB specific polyclonal antibody, Fc $\gamma$ RIIB protein was detected (65). However, skin mast cells lack Fc $\gamma$ RIIB surface expression (66) and using a Fc $\gamma$ RIIB specific $\mathrm{mAb}$, peripheral blood derived mast cells do not express Fc $\gamma$ RIIB (A. Chenoweth personal communication). Neutrophils either lack (60) or express very low levels of Fc $\gamma$ RIIB (59), and the
FcyRIIB-specific mAb 2B6 does not usually stain NK cells (60). However, in that proportion $(\sim 20 \%)$ of the population where Fc $\gamma$ RIIC is expressed, NK staining by Fc $\gamma$ RIIB antibodies might be expected as Fc $\gamma$ RIIC EC domain is identical to Fc $\gamma$ RIIB. A further complication is that Fc $\gamma$ RIIC CNV affects control elements of the FCGR2B gene permitting Fc $\gamma$ RIIB expression in NK cells (67) (see Fc $\gamma$ RIIC below).

One of the more interesting features of Fc $\gamma$ RIIB is its presence on non-leukocyte cells including airway smooth muscle (68) and liver sinusoidal endothelial cells (69). Its abundance in liver, in the mouse, accounting for three quarters of the total body expression, appears to provide a large sink for the removal in IgG immune complexes, which has been exploited in therapeutic monoclonal antibodies whose Fc portions have been engineered for high affinity binding to Fc $\gamma$ RIIB $(70,71)$. This appears to be a "stand alone" function of Fc $\gamma$ RIIB where small immune complexes are internalized without risk of pro-inflammatory activation.

\section{Fc $\gamma$ RIIB Modulation of Immunity}

Fc $\gamma$ RIIB was the first immune "checkpoint" defined (72), with mouse studies showing a pivotal role in controlling autoreactive germinal center B cell activation and survival in mice with dysfunction resulting in loss of tolerance and autoimmunity (73, 74). Mice with humanized immune systems reconstituted with stems cells homozygous for the dysfunctional Fc $\gamma$ RIIB Thr ${ }^{232}$ allele develop autoantibodies with specificities characteristic of lupus and human rheumatoid arthritis (75). This critical action of its ITIM in controlling the ITAM activation pathway is extensively reviewed elsewhere $(25,76)$. The ratio of activating vs. inhibitory receptors is a key factor in determining the cellular threshold for cell activation and resulting immune response (18, 77). An ITIM, consensus amino acid sequence YXXL (where X represents any amino acid), is found in the cytoplasmic domains of both Fc $\gamma$ RIIB1 and Fc $\gamma$ RIIB2. The co-engagement of Fc $\gamma$ RIIB with an activating type receptor such as Fc $\gamma$ RIIA or the B cell antigen receptor (25) modulates their ITAM-mediated activation signal. Fc $\gamma$ RIIB expression on innate effector cells modulates cell activation mediated by activating Fc $\gamma$ Rs, including dendritic cell maturation and antigen presentation. Fc $\gamma$ RIIB also regulates signaling from varied innate cell receptors including TLRs and complement receptors, reviewed in Bournazos et al. (34) and Espeli et al. (78).

Much of the detail in understanding of the ITIM:ITAM system of immune cell modulation has been derived from Fc $\gamma$ RIIB1 ITIM-mediated regulation of the $\mathrm{B}$ cell receptor (BCR) signaling in mouse B cells. Conventional Fc $\gamma$ RIIB-mediated inhibition requires ligand-dependant co-engagement/aggregation of ITAMcontaining receptors $(79,80)$. The Fc $\gamma$ RIIB ITIM modulation targets the two major ITAM driven pathways-ITAM tyrosine phosphorylation, and the generation of phospholipid mediators, e.g., Phosphatidylinositol (3,4,5)-trisphosphate (PIP3). Briefly, src kinases such as Lyn kinase, which participate in the phosphorylation of the ITAM of the ligand-clustered activating receptors, also phosphorylate the Fc $\gamma$ RIIB ITIM of the coaggregated inhibitory receptor. Notably, Fc $\gamma$ RIIB1 has been reported to be phosphorylated by Lyn and Blk, whereas Fc $\gamma$ RIIB2 solely by Blk (81). 
The phosphorylated-ITIM of Fc $\gamma$ RIIB recruits the inositol phosphatases SHIP1 and SHIP2, as is extensively reviewed in Getahun and Cambier (25). The preferential recruitment of SHIP, over SHP1 and SHP2, to the phosphorylated Fc $\gamma$ RIIB cytoplasmic domain is determined by the SHIP SH2 domain's affinity for the pITIM (82). Notably studies of SHIP recruitment to the cytoplasmic domain of mouse Fc $\gamma$ RIIB1 found phosphorylation of $\mathrm{Tyr}^{326}$, outside the ITIM, bound the $\mathrm{SH} 2$ domain of the adaptor Grb2 which bridged and stabilized the Fc $\gamma$ RIIB:SHIP complex (83). Human Fc $\gamma$ RIIB lacks an equivalent tyrosine, and has a small adjacent deletion. It fails to recruit Grb2 but still recruits SHIP1 that modulates BCR-induced Ca mobilization (84). SHIP dephosphorylates phosphatidylinositol species, with the predominant in vivo substrate being phosphatidylinositol 3,4,5-trisphosphate and ultimately recruits p62 Dok to form a highly active membrane localized enzymatic complex. This inhibits the Ras activation pathway, decreases MAP kinase activation and reduced PLC $\gamma$ function leads to less activation of PKC. SHIP-dependent ITIM inhibition of the MAP kinase pathway, together with the antiapoptotic kinase Akt can thereby affect cellular proliferation and survival (25).

The same mechanisms defined for BCR regulation are applicable to human and mouse myeloid cells, where many observations have been confirmed, particularly for Fc $\gamma$ RIIB2 regulation of FceRI $(25,76)$. Overall Fc $\gamma$ RIIB1 and Fc $\gamma$ RIIB2 signaling pathways are similar, however their principal functional difference lies in their localization in the cell membrane. The C1 insertion (85) of Fc $\gamma$ RIIB1 prolongs membrane retention, whereas Fc $\mathrm{R}$ RIIB2 is rapidly internalized. The equivalent $\mathrm{C}^{*}$ sequence in Fc $\gamma$ RIIA3 also alters membrane localization (see above).

An ITIM independent mechanism of $\mathrm{B}$ cell regulation by Fc $\gamma$ RIIB has been reported wherein Fc $\gamma$ RIIB, by binding antigen bound $\operatorname{IgG}$, co-aggregates with the BCR and prevents the membrane organization of BCR and CD19 $(86,87)$. In another mode of regulation of the adaptive humoral response, Fc $\gamma$ RIIB has been reported to be expressed on plasma cells and binding IgG immune complexes and trigger apoptosis (88). Studies have also identified other mechanisms of FcgRIIB modulation of the IgE receptor and the BCR the existence of which in human cells has not been determined. Mouse bone marrow derived mast cells, which differ phenotypically from human mast cells, showed an unconventional Fc $\gamma$ RIIB ITIM-dependent regulation of the high affinity IgE receptor, FceRI, where intracellular mediated coaggregation of FceRI with Fc $\gamma$ RIIB occurs independently of the Fc $\gamma$ RIIB ectodomain binding to antigen complexed IgG (89).

\section{Cellular Responses}

The specific effects of Fc $\gamma$ RIIB signaling are dependent on the context of the co-engaged activating receptors and the cell type. In B cells, Fc $\gamma$ RIIB1 inhibition of the BCR is a critical immune checkpoint for regulating antibody production $(25,90)$. The powerful nature of this immune checkpoint is evident from studies in clinical, genetic, and animal models that show that altering the balance between ITIM modulation and
ITAM activation is central to the pathogenesis and severity of disease (91).

As humoral immune responses develop, circulating antigen:antibody complexes simultaneously engage the antigenspecific BCR via the antigen of the complex and Fc $\gamma$ RIIB via the $\mathrm{Fc}$ region, thereby modulating antigen receptor signaling. In Fc $\gamma$ RIIB1, the $\mathrm{C} 1$ insertion impairs endocytosis, increasing the interaction time between Fc $\gamma$ RIIB1, and the BCR. The $\mathrm{C} 1$ insert, irrespective of its position in the cytoplasmic tail, tethers the receptor to the cytoskeleton and so prevents the receptor localizing to coated pits and so disrupting endocytosis $(92,93)$. A di-leucine motif within the Fc $\gamma$ RIIB ITIM sequence is also required for endocytosis $(93,94)$. Thus, the C1 insert confers cytoskeletal tethering and membrane retention which counter other cytoplasmic tail sequences including the di-leucine residues that would otherwise promote endocytosis.

Fc $\gamma$ RIIB2 has also been studied in B cells in experimental systems where it also co-engages the BCR and regulates its function. Fc $\gamma$ RIIB2 lacks the cytoplasmic C1 insertion and is rapidly internalized. A rare $\mathrm{Tyr}^{235}$ Asp polymorphism occurs within the unique membrane-tethering 19-amino acid insertion of Fc $\gamma$ RIIB1. Fc $\gamma$ RIIB1-Asp ${ }^{235}$ binding of mouse IgG1 was slightly lower in comparison to the $\mathrm{Tyr}^{235}$ variant of Fc $\gamma$ RIIB1, as was mIgG1 anti-CD3 induced $\mathrm{T}$ cell mitogenesis $(95,96)$. Fc $\gamma$ RIIB1-Asp ${ }^{235}$ retained the capacity to form caps and was effective in down-regulating increases in calcium upon crosslinking by serum IgG (95).

This prolonged surface expression of actively signaling Fc $\gamma$ RIIB1 may also be important for the elimination by apoptosis of self-reactive B cells during somatic hyper-mutation (97). Thus, Fc $\gamma$ RIIB1 constrains the selective antigen specificity of the humoral immune system and directs the $\mathrm{B}$ cell production toward an appropriate antibody repertoire.

Fc $\gamma$ RIIB is upregulated after antigen stimulation via immune complexes on follicular DCs (FDCs) (98). FDCs retain immune complexes and recycle them periodically to their plasma membrane, a process believed to be important in development of B cell immune cell memory (99). The presentation of immune complexes by activated FDCs expressing FcyRIIB provides antigens to $\mathrm{B}$ cells in a highly immunogenic form by multimerising the antigens, thus extensively crosslinking multiple BCRs, minimizing B cell Fc $\gamma$ RIIB ITIM-mediated inhibition and providing co-stimulatory signals (100).

The functional response of a cell that expresses both ITAMbearing receptors and Fc $\gamma$ RIIB can be altered by their expression levels. Basophils express activatory FceRI and Fc $\gamma$ RIIA, as well as FcyRIIB, which can inhibit IgE-induced responses $(101,102)$. This balance can be altered by IL-3 which upregulates expression of both Fc $\gamma$ R, but more strongly enhances Fc $\gamma$ RIIB2 expression (101). Under normal physiologic conditions it is believed that Fc $\gamma$ RIIA co-aggregation may, by providing activated Lyn, aid Fc $\gamma$ RIIB inhibitory function (102).

Monocyte-derived dendritic cells (moDCs) that were treated with IFN $\gamma$ to upregulate their activating $F_{c} \gamma$ Rs (Fc $\gamma$ RI and Fc $\gamma$ RIIA) had increased IgG-mediated cellular maturation, while moDCs treated with anti-inflammatory concentrations of soluble monomeric IgG (IVIg) to increase Fc $\gamma$ RIIB expression had 
decreased cellular maturation (18). Similarly, monocytes with increased expression of activating $\mathrm{Fc} \gamma \mathrm{Rs}$ over $\mathrm{Fc} \gamma \mathrm{RIIB}$ as induced by IFN $\gamma$ or TNF $\alpha$ had enhanced IgG-triggered cytokine production, while monocytes with enhanced Fc $\gamma$ RIIB expression by IL- 4 and IL-10 prevented IgG-triggered cytokine production (103). Furthermore, Fc $\gamma \mathrm{RIIB}^{-/-}$mouse macrophages developed robust inflammatory responses after exposure to subthreshold concentrations of immune complexes that failed to induce responses in Fc $\gamma$ RIIB-expressing cells, demonstrating a role of Fc $\gamma$ RIIB in setting a "threshold" for cellular activation (104).

\section{PROPERTIES OF Fc $\gamma$ RIIC}

\section{Molecular Structure}

The expression of the membrane FCGR2C is complex. It is subject to a polymorphism (Gln ${ }^{13}$ STOP) wherein $\sim 80 \%$ of the population do not express functional Fc $\gamma$ RIIC proteins and also $\mathrm{CNV}$, which in turn impacts expression of the FCGR2B gene as described above $(67,105)$. The FCGR2C gene arose by recombination between FCGR2B and FCGR2A. The functional transmembrane Fc $\gamma$ RIIC protein encoded by this gene is an activating receptor wherein the extracellular domains are derived from and are identical to Fc $\gamma$ RIIB (exons 1-4), but the transmembrane and cytoplasmic tail are derived from the activating type ITAM-containing Fc $\gamma$ RIIA (exons 5-8).

Multiple mRNA splice variants of Fc $\gamma$ RIIC have been identified (Figure 1), though their physiology is unclear. Interestingly, some Fc $\gamma$ RIIC-Gln ${ }^{13}$ individuals still lack Fc $\gamma$ RIIC expression due to alternative splicing that gives rise to multiple non-functional forms (67). Additionally, the FCGR2C locus shows CNV, which may contribute to variation in gene expression, at the transcript and/or protein level, also impacting other Fc $\gamma$ RII expression and function $(67,106)$.

\section{Expression and Cellular Responses}

In individuals expressing the activatory Fc $\gamma$ RIIC, it has been most extensively studied on NK cells (Table 1). NK cells expressing Fc $\gamma$ RIIC had increased levels of ADCC upon receptor crosslinking, causing mediator release and lysis of target cells $(67,105-$ 108). Although not extensively studied, it appears that Fc $\gamma$ RIIC is also expressed on CD19+ B Cells. Its co-ligation with the BCR caused enhanced BCR signaling and B cell function, relative to Fc $\gamma$ RIIB ITIM-dependent negative regulation in the absence of Fc $\gamma$ RIIC. This Fc $\gamma$ RIIC expression on B cells is associated with systemic lupus erythematosus (SLE) in humans, possibly related to the altered or unbalanced ITAM/ITIM signaling (108).

Interestingly, multiple other SNPs, 114945036, rs138747765, and rs78603008, have been significantly associated with Fc $\gamma$ RIIA or Fc $\gamma$ RIIC mRNA expression in B cells in European populations (109). However, protein expression data is not yet available.

\section{STRUCTURAL BASIS OF Fc $\gamma$ RII INTERACTION WITH IgG}

Human Fc $\gamma$ Rs have distinct binding specificities and affinities for the four IgG subclasses (2). The determination of affinity and IgG subclass specificity has relied on a wide range of methods
TABLE 3 | Relative binding of human IgG by FcyR expressed on the cell surface.

\begin{tabular}{|c|c|c|c|c|}
\hline \multirow[t]{2}{*}{ Human Fc $\gamma \mathbf{R}$} & \multicolumn{4}{|c|}{ Human IgG Subclass } \\
\hline & IgG1 & $\lg G 2$ & IgG3 & $\operatorname{lgG4}$ \\
\hline Fc $\gamma \mathrm{RIIA} \mathrm{His}^{131}$ & +++ & ++ & ++++ & - \\
\hline Fc $\gamma$ RIIA Arg ${ }^{131}$ & ++ & \pm & ++++ & \pm \\
\hline $\mathrm{F} c \gamma \mathrm{R} \| \mathrm{B}$ & + & - & +++ & + \\
\hline Fc $\gamma R \| I C$ & + & - & +++ & + \\
\hline
\end{tabular}

mostly based on the binding of immune complexes to cellexpressed Fc $\gamma$ R. More sensitive methods have used recombinant ectodomains and monomeric IgG using highly sensitive cell free systems such as $\operatorname{SPR}(5,6,110)$. A survey of the literature on the measurement of specificity and affinity of these receptors shows some variation in the methods used and the values calculated. Even the application of more sophisticated methods such as SPR show some degree of variation from group to group. Notwithstanding the variations and limitation in analyses of the interactions, it is clear that the Fc $\gamma$ RII family (Fc $\gamma$ RIIA, Fc $\gamma$ RIIB, and Fc $\gamma$ RIIC), are sensors of immune complexes and as such, interact poorly with uncomplexed monomeric IgG ( $1 \mu \mathrm{M}$ affinity) but avidly bind immune complexes $(5,6,15,110)$.

There is general agreement that all Fc $\gamma$ RII, indeed all Fc $\gamma$ R, bind human IgG1 and IgG3 but there are significant differences in the interaction with IgG2 and IgG4 (Table 3). The allelic His ${ }^{131}$ form of human Fc $\gamma$ RIIA is the only receptor which avidly binds human IgG2 complexes, while Fc $\gamma$ RIIA-Arg ${ }^{131}$ binds IgG2 poorly (Table 3). However, it is possible that under circumstances of high local concentrations of opsonizing antibodies that binding interactions occur with Fc $\gamma$ RIIA-Arg ${ }^{131}$ though whether there is a functional outcome is unknown $(6,111)$.

In contrast, Fc $\gamma$ RIIB binds IgG4 but not IgG2 and moreover, binds IgG1 and IgG3 an approximately 10-fold lower affinity than the activating Fc $\gamma$ RIIA. This is consistent with its powerful physiological inhibitory function as IgG binding affinities equal to or higher than the activating receptors might otherwise prevent pro-inflammatory responses that are necessary in resisting infection. Not surprisingly, Fc $\gamma$ RIIC has the same IgG binding properties at Fc $\gamma$ RIIB (6).

Other factors that affect interactions between IgG and the FcyRII are the size of the IgG immune complex (112), the distribution of epitopes $(111,113)$, the geometry of the Fc in the complex, and receptor localization in membrane domains (114) which may also influence the avidity of immune complex binding. The state of the cell expressing the receptor (115) can also influence interaction with IgG. Fc $\gamma$ RIIA function may be modified by "inside-out signaling" whereby external stimuli such as granulocyte-macrophage colony-stimulating factor (GM-CSF), IL-5, and IL-3 in eosinophils (116) and $\mathrm{N}$-formylmethionyl-leucyl-phenylalanine (fLMP) in neutrophils increase receptor avidity (117). The mechanism for this Fc $\gamma$ RIIA "activation" is unknown but could involve receptor dimer forms $(5,115,117,118)$. This inside-out signaling has also been identified for the high affinity IgG receptor, Fc $\gamma$ RI, 

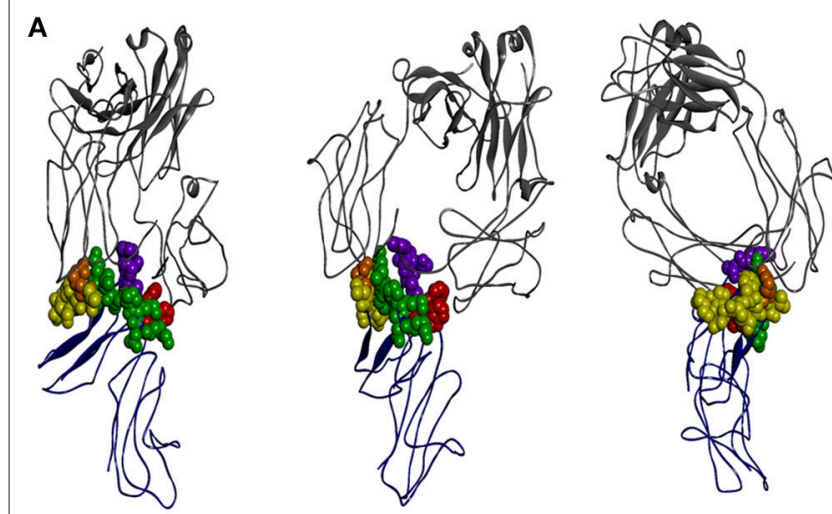

B
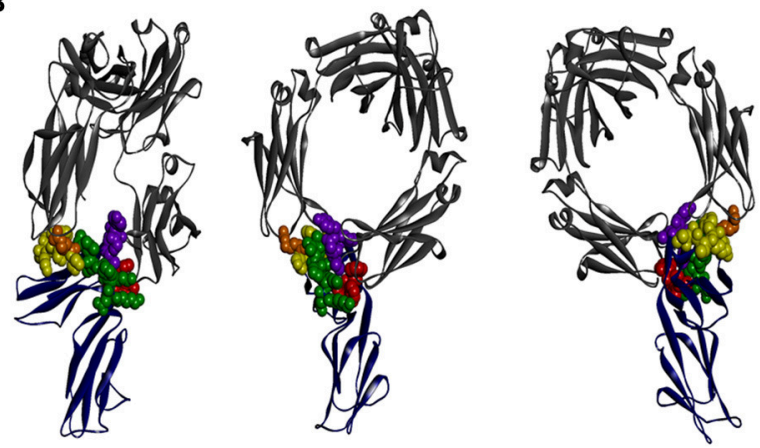

FIGURE 2 | The interaction of IgG-Fc with Fc $\gamma R$ RIIA and $F_{c} \gamma R \| I B$ is similar. The perspectives shown are of two ectodomains of the (A) Fc $\gamma$ RIIA [adapted from 3RY6 (61)] and (B) Fc $\gamma$ RIIB [adapted from 3WJJ (123)] (shown in dark blue) in complex with IgG-Fc (shown in gray). The structural components of the receptor contributing to IgG binding are the two tryptophan residues that form the Trp sandwich (red), the BC loop (green), the C'E strand (yellow), and the FG loop (purple), with the "high/low resonder" polymorphic residue His ${ }^{131} \mathrm{Arg}$ highlighted (orange).

where it is associated with cytoskeletal-dependent clustering of receptors (119).

$\mathrm{X}$-ray crystallographic structural data is available for all Fc $\gamma \mathrm{R}$ but only in complex with the native or mutated IgG1 $(61,120-$ 122). It is clear that the interaction of Fc $\gamma$ RIIA and Fc $\gamma$ RIIB with IgG1 is asymmetric. The "bent" $\mathrm{Fc} \gamma \mathrm{R}$ extracellular region of one Fc $\gamma \mathrm{R}$ molecule inserting between, and making contacts with, both IgG1 H-chain Fcs, as is also the case with other Fc $\gamma \mathrm{R}$ (Figure 2) $(2,124)$. The key conclusion from these studies is that the principal contact regions of the Fc $\gamma$ RIIA and Fc $\gamma$ RIIB are similar and occur predominantly within the second domain $\mathrm{BC}$ loop, C strand, $\mathrm{C}^{\prime} \mathrm{E}$ loop, and the FG loop, with a contribution of the interdomain linker. The BC loop and the interdomain linker provide the two critical tryptophan residues, conserved in all Fc $\gamma$ R, that sandwich the Pro ${ }^{331}$ of the IgG1 CH2 FG loop.

The lower hinge of IgG has a dominant role in determining the specificity of $\mathrm{Fc} \gamma \mathrm{R}$ interactions. In the case of IgG1, the lower hinge residues, $\operatorname{Pro}^{233} \mathrm{Leu}^{234} \mathrm{Leu}^{235} \mathrm{Gly}^{236} \mathrm{Gly}^{237}$, of both $\mathrm{H}$-chains form extensive contacts with Fc $\gamma$ RIIA (61). Interestingly, this region is quite different in IgG2 (Pro,Val,Ala,Gly) and suggests that the IgG2 interaction with Fc $\gamma$ RIIA may be quite distinct at the atomic level but as yet no structure of IgG2 in complex with Fc $\gamma$ RIIA is known. Nonetheless, the IgG1:Fc $\gamma$ RIIA complex structure suggests that the preferential IgG2 binding by Fc $\gamma$ RIIA-H ${ }^{131}$ over Fc $\gamma$ RIIA$\mathrm{R}^{131}$-the "high/low responder" polymorphism (125) - may be explained structurally by the smaller histidine side chain more readily accommodating interaction with the $\mathrm{Fc}$ adjacent to the lower hinge compared to the longer arginine side chain (61).

The structural basis for the effect of the rare $G \ln ^{127}$ Lys polymorphism that also affects IgG2 binding is interesting (126). The Lys ${ }^{127}$ does not appear to make contact with the IgG1 Fc and sits adjacent to the binding region, so that the effect on Fc binding is presumably indirect. This indicates a possible selective pressure for IgG2 binding by this receptor (126).

\section{ROLES OF Fc $\gamma$ RII IN HEALTH AND DISEASE}

The balance between activation and inhibitory signaling is important in the control of healthy antibody dependant responses and disturbance to this balance can have adverse, but in some cases positive, consequences to health.

Genetic polymorphism studies of human FCGR2 genes have helped to establish roles of Fc $\gamma$ RII proteins in several autoimmune diseases and in resistance or susceptibility to infectious diseases (Table 4). In vivo mechanistic studies in experimental animal models, including transgenic and gene replacement systems, have also been helpful in establishing specific protective or deleterious roles of Fc $\gamma$ RII in infectious disease, inflammation, autoimmunity, and cancer and have been reviewed extensively elsewhere (139-143).

\section{Infection}

The in vivo roles of the FcyRII receptor family in humans have been derived by extrapolation of animal studies and by genetic studies of human populations. The Fc $\gamma$ RIIA high/lowresponder polymorphism influences susceptibility to infections, as Fc $\gamma$ RIIA-Arg ${ }^{131}$ has poor IgG2 binding $(144,145)$. Individuals expressing Fc RIIA-His $^{131}$ are more resistant to infection by Streptococcus pneumonia, Haemophilus influenza, and Neisseria meningitides. This is potentially due to more avid binding of IgG2 by Fc $\gamma$ RIIA-His ${ }^{131}$ over Fc $\gamma$ RIIA-Arg ${ }^{131}$, consequently resulting in more efficient effector responses such as uptake by phagocytes, induction of degranulation and elastase release by granulocytes in vivo $(144,146,147)$.

Fc $\gamma$ Rs do not function in isolation under physiological conditions in vivo and it is notable that co-operation between Toll-like receptors (TLRs) and Fc $\gamma$ Rs is an important feature of effective pathogen elimination (148). TLRs are often co-expressed with Fc $\gamma$ RIIA and co-engagement results in enhanced functional responses of these individual receptors, e.g., enhanced $\mathrm{TNF} \alpha$, IL-23, and IL- $1 \beta$ release by DCs $(35,149,150)$.

The role of $\mathrm{Fc} \gamma \mathrm{R}$ in HIV is complex and apparently conflicting data may reflect different aspects of HIV infection and clinical outcomes. In a small study of immunocompetent patients who had undergone successful and early antiretroviral treatment, who expressed Fc $\gamma$ RIIA-His ${ }^{131}$, and had a IgG2 response 
TABLE 4 | Function or clinical association of polymorphic residues of FcyRll.

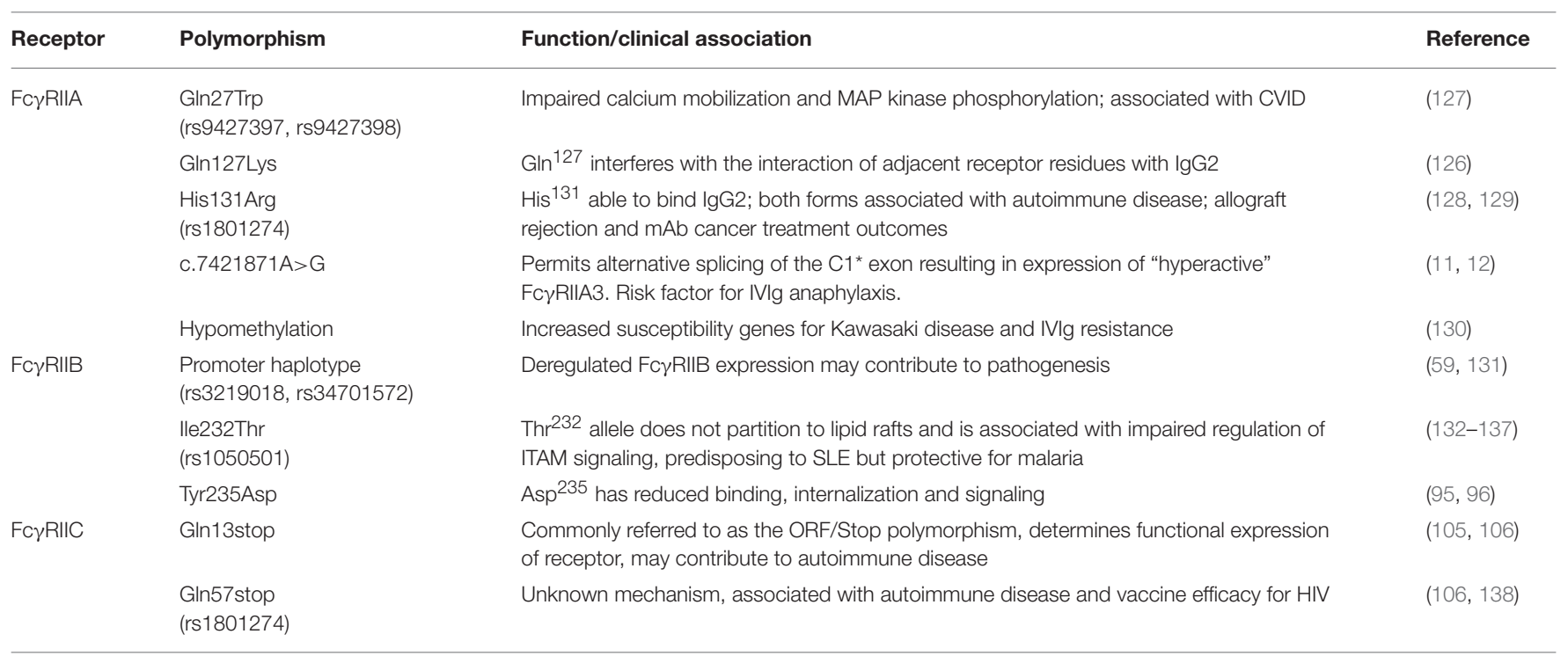

to a gp120 vaccine regime, there was a partial control of viral replication during interruption of anti-retroviral therapy (151). However, analysis of the Vax004 gp120 vaccine trial found no evidence of association of Fc $\gamma$ RIIA polymorphism with protection against HIV infection, although this was an unsuccessful vaccine trial overall (152). HIV studies have emphasized the protective role of NK cell Fc $\gamma$ RIIIA in antibody dependent cellular cytotoxicity. However, recent studies have found a potent role for Fc $\gamma$ RIIA in the protective functions of macrophages and neutrophils, which are abundant effectors at the mucosal sites of HIV acquisition (153). HIV co-infections generate an even more complex clinical picture. Fc $\gamma$ RIIA-His ${ }^{131}$ homozygous individuals are more susceptible to developing AIDs-related pneumonia, and have an increased risk of placental malaria in HIV-infected women (154) and other perinatal infections $(155,156)$.

While few resting CD4 T cells express Fc $\gamma$ RIIA, these cells are highly relevant to HIV research. Resting CD4 T cells latently infected with HIV are an important target in strategies to eliminate $\mathrm{HIV}$ in anti-retroviral therapy (ART) patients, as these quiescent cells provide safe harbor for "silent" virus that, upon reactivation, causes viral recrudescence within weeks of treatment interruption. Fc $\gamma$ RIIA was reported as a surface marker of this key quiescent population in ART patients (157) but other studies found no enrichment of HIV proviral DNA by sorting CD4 T cells based on Fc $\gamma$ RIIA expression $(52,158)$. Rather than on resting CD4 T cells, Fc $\gamma$ RII expression was mostly on activated CD4 cells associated with transcriptionally active virus (159). Furthermore, another study sorted a CD4 ${ }^{+}$ population that apparently expressed Fc $\gamma$ RIIB, not Fc $\gamma$ RIIA. However, these $\mathrm{Fc}_{\mathrm{RIIB}}{ }^{+}$cells derived from contaminating $B$ cells, occurring as T-B cell doublets, and also from single CD4 T cells, with a punctate staining pattern that included other $\mathrm{B}$ cell markers, and was suggestive of trogocytosis rather than intrinsic CD4 T cell expression (52). These studies indicate some of the technical challenges that can accompany determining Fc $\gamma$ R expression.

Though the numbers are small there is suggestive evidence that polymorphism in the FCGR2C locus, in particular FCGR2C$126 \mathrm{C}>\mathrm{T}$ SNP was associated with a protective anti-HIV vaccination response. In the RV144 vaccine trial, individuals homozygous for FCGR2C-126C/C had an estimated vaccine efficacy of $15 \%$ whereas individuals homozygous for the FCGR2C-126T/T or heterozygous $-126 \mathrm{C} / \mathrm{T}$ had an estimated vaccine efficacy of $91 \%$ (138). Whether this association relates to effector function via a functional Fc $\gamma$ RIIC protein or is due to linkage to another effector system encoded in this chromosomal region is uncertain (109).

Fc $\gamma$ Rs also have an established role in antibody-dependent enhancement (ADE) of dengue virus (DENV) infection. Immune complexes of DENV opsonized with non- or subneutralizing levels of antibodies interact with Fc $\gamma$ Rs on monocytes, macrophages, and dendritic cells, led to increased uptake, viral replication, and more severe infection (160). In keeping with its modulating role, Fc $\gamma$ RIIB inhibits ADE in experimental systems (161). Indeed, while Fc $\gamma$ RIIA facilitates DENV entry, mutation of the ITAM to an ITIM significantly inhibited ADE, and conversely, replacing the inhibitory motif in Fc $\gamma$ RIIB with an ITAM, conferred ADE capacity (162).

The hypo-functional Fc $\gamma$ RIIB-Thr ${ }^{232}$ variant is enriched in populations from malaria endemic areas. This suggests that reduced Fc $\gamma$ RIIB modulation of responses and a consequential enhancement of $\mathrm{B}$ cell and inflammatory cell activation confers a survival advantage in these populations $(132,163)$. Indeed, enhanced activatory FcR responses including increased phagocytic capacity and TNF production by innate cells and enhanced B cell responses is evident by elevated malaria specific antibody titers (164).

Interestingly, the Fc $\gamma$ RIIB-Thr ${ }^{232}$ polymorphism has been shown to confer increased phagocytosis of antibody opsonized 
bacteria by monocyte-derived macrophages (132). Models suggest Fc $\mathrm{R}$ RIB is integral for the balance between efficient pathogen clearance and the prevention of the cytokine-mediated effects of sepsis (163). In geographic areas where there is less infectious disease pressure, Fc $\gamma$ RIIB-Thr ${ }^{232}$ is associated with susceptibility to autoimmunity.

\section{Fc $\gamma R$ in Autoimmunity}

Imbalance between inhibitory and activatory $\mathrm{Fc} \gamma \mathrm{R}$ functions predisposes individuals to pro-inflammatory autoimmune disease. Fc $\gamma$ RIIA activation induces the production of proinflammatory cytokines, including IFN and TNF $\alpha$, which are active in the promotion of inflammation, systemic lupus erythematosus (SLE), Kawasaki disease (KD), Grave's disease, and Rheumatoid Arthritis (RA) (35, 165-167).

The Fc $\gamma$ RIIA-His ${ }^{131}$ allelic form is associated with other autoimmune diseases, including Guillain-Barré syndrome, ulcerative colitis and $\mathrm{KD}$, possibly due to increased inflammatory cell activation via IgG2 (168-170).The Fc $\gamma$ RIIA-Arg ${ }^{131}$ allelic form is associated with susceptibility to SLE, angina pectoris, acute coronary syndrome (ACS), myasthenia gravis, and RA (171-174). This may be related to the impaired ability of Fc $\gamma$ RIIA-Arg ${ }^{131}$ to process and recycle IgG2, causing the release of pro-inflammatory cytokines, aggravating disease $(175,176)$.

Other FcyRIIA polymorphisms, although less well characterized, are associated with inflammatory diseases. Recently a glutamine/tryptophan polymorphism at position 27 (Gln ${ }^{27} \mathrm{Trp}$ ) has been identified, where homozygous individuals were over represented in CVID (127). No difference in expression was observed and Fc $\gamma$ RIIA-Trp ${ }^{27}$ had modest impairment of calcium mobilization and MAP kinase phosphorylation in vitro (127).

Epigenetic modifications of FCGR2A such as hypomethylation have also been described in CVID patients, particularly at the promoter CpG site cg24422489 (130, 169). This increased susceptibility for $\mathrm{KD}$ and resistance to Ig replacement therapy, with significant hypomethylation of Fc $\gamma$ RIIA in patients with acute KD and coronary artery lesions $(130,169,177)$.

The recently described rare intronic $A>G$ SNP that controls expression of the splice variant Fc $\gamma$ RIIA3 occurs in $<1 \%$ of healthy subjects $(11,12)$. However, it is associated with $\mathrm{KD}$, immune thrombocytopenia (ITP), and CVID (11). Furthermore, severe adverse reactions in response to immunoglobulin replacement therapy occurred in patients expressing Fc $\gamma$ RIIA3 and neutrophil activation (mediator and elastase release) was enhanced. Increased signaling by Fc $\gamma$ RIIA 3 was due to its altered membrane localization and longer membrane retention time (11, 12). Thus, increased inflammatory responses toward therapeutic IgG may paradoxically diminish the utility of the major treatment regime in this subset of CVID patients.

Polymorphism and CNV of activatory Fc $\gamma$ RIIC is associated with increased severity of RA and ITP $(106,178)$. This has been attributed to expression variance in these individuals causing an imbalance between activatory and inhibitory signals.

Since the inhibitory Fc $\gamma$ RIIB forms modulate the activation of $B$ cells and innate effector cells, decreased expression of the Fc $\gamma$ RIIB leads to dysregulated antibody function and increased antibody-dependant inflammatory cell responses and thus increased susceptibility to autoimmune diseases. Polymorphisms in the FCGR2B promoter or transmembrane domain of Fc $\gamma$ RIIB influence receptor expression and signaling potency and are associated with susceptibility to autoimmune diseases including SLE, Goodpasture's disease, ITP, and RA (133-135, 156, 179, 180). Multiple polymorphisms in the promoter region of FCGR2B have been identified. The promoter haplotype FCGR2B-386G $>\mathrm{C}$ SNP in combination with FCGR2B-120T $>$ A SNP (FCGR2B$386 \mathrm{C}+-120 \mathrm{~A})$ enhances promoter activity and transcription, however this enhanced haplotype has low prevalence $(59,131)$. FCGR2B-343G $>$ C SNP is enriched in European American SLE patients and homozygous expression of FCGR2B-343C is linked to SLE susceptibility $(131,179)$. This is due to decreased AP1 transcription complex binding, which causes decreased Fc $\gamma$ RIIB expression on $\mathrm{B}$ cells and macrophages and altered antigen clearance (179).

The frequency of the transmembrane polymorphism Fc $\gamma$ RIIB-Thr ${ }^{232}$ Ile differs among different ethnic populations, with Fc $\gamma$ RIIB-Thr ${ }^{232}$ associated with SLE in Asian but not African American or European populations (134). Fc $\gamma$ RIIB$\mathrm{Thr}^{232}$ shows reduced lateral mobility in the membrane which impairs its ability to inhibit the co-localization of BCR and CD19 microclusters and consequent B cell activation (181). This causes increased B cell and myeloid cell activation (133, 136, 137), which elevates B cell (antibody) responses and heightens IgG-dependant pro-inflammatory responses, resulting in autoimmunity.

\section{Cancer}

The roles of $\mathrm{Fc} \gamma \mathrm{R}$ in cancer relate largely to the harnessing of antibody-dependant effector functions such as ADCC or ADCP by therapeutic mAbs during the treatment [reviewed in $(2,139)]$. However, it also appears that mAb therapy may also have long term therapeutic benefits. Studies on DCs indicate that Fc $\gamma$ RIIA activation is necessary and sufficient to induce a strong $\mathrm{T}$ cell anti-tumor cellular immunity inducing long term anti-tumor vaccine-like or "vaccinal effects" in humanized mice (48). Engagement of Fc $\gamma$ RIIA induced DC maturation and upregulation of costimulatory molecules, priming them for optimal antigen presentation and cross-presentation, thus stimulating long-term anti-tumor T cell memory (48).

Conversely, the inhibitory role of FcyRIIB may be disadvantageous to antibody-based therapies and other immune stimulating therapies. Thus, blocking inhibitory function of Fc $\gamma$ RIIB on effector cells or antigen presenting cells such as DCs might be a strategy to enhance anti-tumor immune responses during immunotherapy $(18,182,183)$.

\section{HARNESSING OR TARGETING Fc $\gamma$ RII FOR ANTIBODY BASED THERAPIES}

Monoclonal antibodies are a versatile class of biotherapeutic drugs because of the multifunctional nature of the antibody molecule. IgG-based therapeutic mAbs are effective for the treatment of a variety of diseases due to their high specificity 
and affinity for their target antigen and, in some cases, their strong induction of $\mathrm{Fc} \gamma \mathrm{R}$ effector functions. Depending on the nature of the disease and molecule, the mAb efficacy may depend on one or more mechanisms of action, ranging from simple antigen neutralization, complement-dependent cytotoxicity, Fc $\gamma$ R-dependant cellular effector functions, or inhibition via Fc $\gamma$ RIIB. Thus, effective patient responses can be dependent on Fc $\gamma \mathrm{R}$ based mechanisms, e.g., altered binding due to the Fc $\gamma$ RIIA-His ${ }^{131}$ Arg polymorphism, which influence the efficacy of therapeutic mAbs such as rituximab and cetuximab $(184,185)$.

The efficacy of the anti-EGFR mAb, cetuximab, and subsequent progression free survival was associated with expression of the His ${ }^{131}$ variant of Fc $\gamma$ RIIA (185). Patients with the Fc $\gamma$ RIIA-His ${ }^{131}$ genotype also responded better to rituximab treatment in non-Hodgkin's lymphoma (184). Conversely, Fc $\gamma$ RIIB expression on lymphoma cells is a risk factor for anti$\mathrm{CD} 20$ rituximab therapy failure due to Fc $\gamma$ RIIB internalizing the CD20:rituximab complex and thereby reducing exposure of the opsonized lymphoma cell to the immune effector systems (186).

Inhibition of activatory Fc $\gamma \mathrm{R}$ could block early development of inflammatory disease. This has been explored experimentally in humanized mouse models of RA, using antibody fragments (or small molecules) designed to bind human Fc $\gamma$ RIIA to inhibit disease $(29,187)$. Synthetic FcR mimetics have also been used to block the function of Fc $\gamma$ RIIA in vitro (188) and the modulation of Fc $\gamma$ RIIA and Fc $\gamma$ RIIB function in humans (189).

Fc $\gamma$ RIIB is a powerful modulator of ITAM-dependent receptors such as the BCR or high affinity FceRI. Strategies to harness this powerful inhibitory capacity are being developed by engineering $\mathrm{mAb} F \mathrm{c}$ regions with enhanced and/or selective engagement with Fc $\gamma$ RIIB. Such strategies rely on the coengagement of Fc $\gamma$ RIIB with the mAb-targeted activating receptor. This engineering of therapeutic mAbs with increased affinity to Fc $\gamma$ RIIB has diverse clinical applications. Indeed, antiCD19 binds the BCR complex and the engineered Fc co-engages Fc $\gamma$ RIIB with increased affinity, suppressing B cell activation without B cell depletion $(190,191)$. This novel approach to treat autoimmune disease demonstrates the importance of understanding $\mathrm{Fc} \gamma \mathrm{R}$ biology and interactions with IgG in order to optimally exploit antibody functions for specific therapies.

Another example is the anti-IgE, omalizumab, an effective treatment for allergic asthma by neutralizing IgE binding to FceRI. Mutations introduced in XmAb7195, an omalizumab "equivalent" antibody, enhanced affinity for Fc $\gamma$ RIIB. Like omalizumab, XmAb7195 binds to and neutralizes circulating IgE (71). However, its enhanced Fc interaction with Fc $\gamma$ RIIB may also promote co-aggregation of Fc $\gamma$ RIIB with the BCR of IgE+ $\mathrm{B}$ cells, and may suppress activation of the BCR, diminishing allergic antibody production. In addition, data from mouse studies suggest that the XmAb7195:IgE complexes are rapidly

\section{REFERENCES}

1. Hogarth PM. Fc receptors are major mediators of antibody based inflammation in autoimmunity. Curr Opin Immunol. (2002) 14:798-802. doi: 10.1016/S0952-7915(02)00409-0 removed from the circulation via Fc $\gamma$ RIIB expressed in the liver endothelium (71).

\section{Fc $\gamma R$ Targeted Therapies}

In some autoimmune diseases, auto-antibodies activate inflammatory cell effector functions against self-antigens leading to tissue destruction. One strategy used to ameliorate this destructive pathogenesis is the use of soluble Fc $\gamma$ Rs, which compete for auto-antibody binding with cell-based Fc $\gamma$ Rs thereby preventing induction of the cell-based effector functions $(1,9)$. Pre-clinical studies have demonstrated that the use of these soluble Fc $\gamma$ Rs suppresses the Arthus reaction, collagen-induced arthritis, and SLE (192, 193). A soluble recombinant form of Fc $\gamma$ RIIB, named SM101, is a potential treatment for the treatment of ITP and SLE and has progressed into clinical trials $(194,195)$.

Small chemical entities (SCEs) specific for Fc $\gamma$ RIIA have also been reported to inhibit immune complex-induced responses including platelet activation and aggregation, and TNF secretion by macrophages in vitro (187). Furthermore, in vivo testing of these SCEs in FcrRIIA transgenic mice also inhibited the development and stopped the progression of collageninduced arthritis (CIA) (187). Hence, these SCE Fc $\gamma$ RIIA antagonists demonstrated their potential as anti-inflammatory agents for pro-inflammatory immune complex-dependent autoimmune diseases.

\section{CONCLUSIONS}

Fc $\gamma$ RII receptors and their variants play important roles in the healthy immune response to infection, as well as in the pathologies of autoimmunity and the efficacy of therapeutic $\mathrm{mAb}$ treatments in cancer. Our expanding knowledge of these widely expressed $\mathrm{F} c \gamma \mathrm{R}$ and their signaling pathways may provide insight as to how we can exploit this intricate immunomodulatory system for therapeutic and diagnostic purposes. Harnessing FcRdependent cellular effector systems through therapeutic mAbs, or by blocking effector functions, is becoming an increasingly useful tool to treat an extensive range of diseases.

\section{AUTHOR CONTRIBUTIONS}

JA drafted the manuscript. AC, BW, and $\mathrm{PMH}$ provided additional text and all authors reviewed the manuscript.

\section{FUNDING}

This work was funded by Australian National Health and Medical Research Council: PMH, JA, AC, and BW supported by NHMRC project grants 1079946, 1067484, and grants-in-aid from the Pendergast Trust and Walkom Trust.

2. Hogarth PM, Pietersz GA. Fc receptor-targeted therapies for the treatment of inflammation, cancer and beyond. Nat Rev Drug Discov. (2012) 11:311-31. doi: $10.1038 / \mathrm{nrd} 2909$

3. Qiu WQ, De Bruin D, Brownstein BH, Pearse R, Ravetch JV. Orgaization of the human and mouse low-affinity $\mathrm{Fc} \gamma \mathrm{R}$ genes: duplication an 
recombination. Science. (1990) 248:732-5. doi: 10.1126/science. 2139735

4. Brooks DG, Qiu WQ, Luster AD, Ravetch JV. Structure and expression of human IgG FcRII(CD32). Functional heterogeneity is encoded by the alternatively spliced products of multiple genes. J Exp Med. (1989) 170:136985. doi: $10.1084 /$ jem.170.4.1369

5. Powell MS, Barton PA, Emmanouilidis D, Wines BD, Neumann GM, Peitersz GA, et al. Biochemical analysis and crystallisation of Fc gamma RIIa, the low affinity receptor for Ig. Immunol Lett G. (1999) 68:17-23. doi: 10.1016/S0165-2478(99)00025-5

6. Bruhns P, Iannascoli B, England P, Mancardi DA, Fernandez N, Jorieux $S$, et al. Specificity and affinity of human Fcgamma receptors and their polymorphic variants for human IgG subclasses. Blood. (2009) 113:3716-25. doi: 10.1182/blood-2008-09-179754

7. Lu J, Mold C, Du Clos TW, Sun PD. Pentraxins and Fc receptormediated immune responses. Front Immunol. (2018) 9:2607. doi: 10.3389/fimmu.2018.02607

8. Hibbs ML, Bonadonna L, Scott BM, McKenzie IF, Hogarth PM. Molecular cloning of a human immunoglobulin G Fc receptor. Proc Natl Acad Sci USA. (1988) 85:2240-4. doi: 10.1073/pnas.85.7.2240

9. Ierino FL, Hulett MD, McKenzie IF, Hogarth PM. Mapping epitopes of human Fc gamma RII (CDw32) with monoclonal antibodies and recombinant receptors. J Immunol. (1993) 150:1794-803.

10. Ierino FL, Powell MS, McKenzie IFC, Hogarth PM. Recombinant soluble human Fc gamma RII: production, characterization, and inhibition of the Arthus reaction. J Exp Med. (1993) 178:1617-28. doi: 10.1084/jem.178.5.1617

11. van der Heijden J, Geissler J, van Mirre E, van Deuren MJ, van der Meer W, Salama ATK, et al. A novel splice variant of FcgammaRIIa: a risk factor for anaphylaxis in patients with hypogammaglobulinemia. J Allergy Clin Immunol. (2013) 131:1408-16 e5. doi: 10.1016/j.jaci.2013. 02.009

12. Anania JC, Trist HT, Palmer CS, Tan PS, Kouskousis BP, Chenoweth $\mathrm{AM}$, et al. The rare anaphylaxis-associated Fc $\gamma$ RIIa3 exhibits distinct characteristics from the canonical Fc $\gamma$ RIIal. Front Immunol. (2018) 9:1809. doi: 10.3389/fimmu.2018.01809

13. Amigorena S, Bonnerot C, Drake JR, Choquet D, Hunziker W, Guillet JG, et al. Cytoplasmic domain heterogeneity and functions of IgG Fc receptors in B lymphocytes. Science. (1992) 256:1808-12. doi: 10.1126/science.1535455

14. Astier A, de la Salle H, de la Salle C, Bieber T, Esposito-Farese ME, Freund M, et al. Human epidermal Langerhans cells secrete a soluble receptor for IgG (Fc gamma RII/CD32) that inhibits the binding of immune complexes to $\mathrm{Fc}$ gamma R+ cells. J Immunol. (1994) 152:201-12.

15. Trist HM, Tan PS, Wines BD, Ramsland PA, Orlowski E, Stubbs J, et al. Polymorphisms and interspecies differences of the activating and inhibitory FcgammaRII of Macaca nemestrina influence the binding of human IgG subclasses. J Immunol. (2014) 192:792-803. doi: 10.4049/jimmunol.1301554

16. Hogarth PM, Anania JC, Wines BD. The FcgammaR of humans and non-human primates and their interaction with IgG: implications for induction of inflammation, resistance to infection and the use of therapeutic monoclonal antibodies. Curr Top Microbiol Immunol. (2014) 382:321-52. doi: 10.1007/978-3-319-07911-0_15

17. Hulett MD, Hogarth PM. Molecular basis of Fc receptor function. $A d v$ Immunol. (1994) 57:1-127. doi: 10.1016/S0065-2776(08)60671-9

18. Boruchov AM, Heller G, Veri MC, Bonvini E, Ravetch JV, Young JW. Activating and inhibitory IgG Fc receptors on human DCs mediate opposing functions. J Clin Invest. (2005) 115:2914-23. doi: 10.1172/JCI 24772

19. Shushakova N, Skokowa J, Schulman J, Baumann U, Zwirner J, Schmidt RE, et al. C5a anaphylatoxin is a major regulator of activating versus inhibitory FcgammaRs in immune complex-induced lung disease. J Clin Invest. (2002) 110:1823-30. doi: 10.1172/JCI16577

20. Guyre PM, Morganelli PM, Miller R. Recombinant immune interferon increases immunoglobulin G Fc receptors on cultured human mononuclear phagocytes. J Clin Invest. (1983) 72:393-7. doi: 10.1172/JCI110980

21. te Velde AA, de Waal Malefijt R, Huijbens RJ, de Vries JE, Figdor CG. IL-10 stimulates monocyte Fc gamma R surface expression and cytotoxic activity. Distinct regulation of antibody-dependent cellular cytotoxicity by IFN-gamma, IL-4, and IL-10. J Immunol. (1992) 149:4048-52.
22. Engelhardt W, Matzke J, Schmidt RE. Activation-dependent expression of low affinity IgG receptors $\mathrm{Fc}$ gamma $\mathrm{RII}(\mathrm{CD} 32)$ and $\mathrm{Fc}$ gamma RIII(CD16) in subpopulations of human T lymphocytes. Immunobiology. (1995) 192:297-320. doi: 10.1016/S0171-2985(11)80172-5

23. Holgado MP, Sananez I, Raiden S, Geffner JR, Arruvito L. CD32 ligation promotes the activation of CD4(+) T cells. Front Immunol. (2018) 9:2814. doi: 10.3389/fimmu.2018.02814

24. Metzger H. Transmembrane signaling: the joy of aggregation. J Immunol. (1992) 149:1477-87.

25. Getahun A, Cambier JC. Of ITIMs, ITAMs, and ITAMis: revisiting immunoglobulin Fc receptor signaling. Immunol Rev. (2015) 268:66-73. doi: $10.1111 / \mathrm{imr} .12336$

26. Barrow AD, Trowsdale J. You say ITAM and I say ITIM, let's call the whole thing off: the ambiguity of immunoreceptor signalling. Eur J Immunol. (2006) 36:1646-53. doi: 10.1002/eji.200636195

27. Mkaddem SB, Murua A, Flament H, Titeca-Beauport D, Bounaix C, Danelli L, et al. Lyn and Fyn function as molecular switches that control immunoreceptors to direct homeostasis or inflammation. Nat Commun. (2017) 8:246. doi: 10.1038/s41467-017-00294-0

28. Ganesan LP, Fang H, Marsh CB, Tridandapani S. The protein-tyrosine phosphatase SHP-1 associates with the phosphorylated immunoreceptor tyrosine-based activation motif of $\mathrm{Fc}$ gamma RIIa to modulate signaling events in myeloid cells. J Biol Chem. (2003) 278:35710-7. doi: $10.1074 /$ jbc.M305078200

29. Ben Mkaddem S, Hayem G, Jonsson F, Rossato E, Boedec E, Boussetta T, et al. Shifting FcgammaRIIA-ITAM from activation to inhibitory configuration ameliorates arthritis. J Clin Invest. (2014) 124:3945-59. doi: $10.1172 / J C I 74572$

30. Campbell KS. Suppressing the killer instinct. Sci Signal. (2016) 9:fs8. doi: $10.1126 /$ scisignal.aaf6348

31. Kanamaru Y, Pfirsch S, Aloulou M, Vrtovsnik F, Essig M, Loirat C, et al. Inhibitory ITAM signaling by $\mathrm{Fc}$ alpha RI-FcR gamma chain controls multiple activating responses and prevents renal inflammation. J Immunol. (2008) 180:2669-78. doi: 10.4049/jimmunol.180.4.2669

32. Rossato E, Ben Mkaddem S, Kanamaru Y, Hurtado-Nedelec M, Hayem G, Descatoire V, et al. Reversal of Arthritis by Human Monomeric IgA Through the Receptor-Mediated SH2 Domain-Containing Phosphatase 1 Inhibitory Pathway. Arthritis Rheumatol. (2015) 67:1766-77. doi: 10.1002/art. 39142

33. Aloulou M, Ben Mkaddem S, Biarnes-Pelicot M, Boussetta T, Souchet H, Rossato E, et al. IgG1 and IVIg induce inhibitory ITAM signaling through FcgammaRIII controlling inflammatory responses. Blood. (2012) 119:308496. doi: 10.1182/blood-2011-08-376046

34. Bournazos S, Wang TT, Ravetch JV. The role and function of Fcgamma receptors on myeloid cells. Microbiol Spectr. (2016) 4:6. doi: 10.1128/microbiolspec.MCHD-0045-2016

35. Vogelpoel LT, Baeten DL, de Jong EC, den Dunnen J. Control of cytokine production by human fc gamma receptors: implications for pathogen defense and autoimmunity. Front Immunol. (2015) 6:79. doi: $10.3389 /$ fimmu.2015.00079

36. Booth JW, Kim MK, Jankowski A, Schreiber AD, Grinstein S. Contrasting requirements for ubiquitylation during $\mathrm{FC}_{\mathrm{C}}$ receptor-mediated endocytosis and phagocytosis. EMBO J. (2002) 21:251-8. doi: 10.1093/emboj/21.3.251

37. Zhang CY, Booth JW. Differences in endocytosis mediated by FcgammaRIIA and FcgammaRIIB2. Mol Immunol. (2011) 49:329-37. doi: 10.1016/j.molimm.2011.09.003

38. Indik Z, Kelly C, Chien P, Levinson AI, Schreiber AD. Human Fc gamma RII, in the absence of other $\mathrm{Fc}$ gamma receptors, mediates a phagocytic signal. $J$ Clin Invest. (1991) 88:1766-71. doi: 10.1172/JCI115496

39. Dai X, Jayapal M, Tay HK, Reghunathan R, Lin G, Too CT, et al. Differential signal transduction, membrane trafficking, and immune effector functions mediated by FcgammaRI versus FcgammaRIIa. Blood. (2009) 114:318-27. doi: 10.1182/blood-2008-10-184457

40. Huang ZY, Chien P, Indik ZK, Schreiber AD. Human platelet FcgammaRIIA and phagocytes in immune-complex clearance. Mol Immunol. (2011) 48:691-6. doi: 10.1016/j.molimm.2010.11.017

41. Chen K, Nishi H, Travers R, Tsuboi N, Martinod K, Wagner DD, et al. Endocytosis of soluble immune complexes leads to their clearance by 
FcgammaRIIIB but induces neutrophil extracellular traps via FcgammaRIIA in vivo. Blood. (2012) 120:4421-31. doi: 10.1182/blood-2011-12-401133

42. Worth RG, Chien CD, Chien P, Reilly MP, McKenzie SE, Schreiber AD. Platelet FcgammaRIIA binds and internalizes IgG-containing complexes. Exp Hematol. (2006) 34:1490-5. doi: 10.1016/j.exphem.2006.06.015

43. Richards JO, Karki S, Lazar GA, Chen H, Dang W, Desjarlais JR. Optimization of antibody binding to FcgammaRIIa enhances macrophage phagocytosis of tumor cells. Mol Cancer Ther. (2008) 7:2517-27. doi: 10.1158/1535-7163.MCT-08-0201

44. Sallusto F, Lanzavecchia A. Efficient presentation of soluble antigen by cultured human dendritic cells is maintained by granulocyte/macrophage colony-stimulating factor plus interleukin 4 and downregulated by tumor necrosis factor alpha. J Exp Med. (1994) 179:1109-18. doi: 10.1084/jem.179.4.1109

45. Wallace PK, Tsang KY, Goldstein J, Correale P, Jarry TM, Schlom J, et al. Exogenous antigen targeted to FcgammaRI on myeloid cells is presented in association with MHC class I. J Immunol Methods. (2001) 248:183-94. doi: 10.1016/S0022-1759(00)00351-3

46. Platzer B, Stout M, Fiebiger E. Antigen cross-presentation of immune complexes. Front Immunol. (2014) 5:140. doi: 10.3389/fimmu.2014.00140

47. Amigorena $\mathrm{S}$. Fc gamma receptors and cross-presentation in dendritic cells. J Exp Med. (2002) 195:F1-3. doi: 10.1084/jem.20011925

48. DiLillo DJ, Ravetch JV. Differential Fc-receptor engagement drives an anti-tumor vaccinal effect. Cell. (2015) 161:1035-45. doi: 10.1016/j.cell.2015.04.016

49. Graziano RF, Fanger MW. Fc gamma RI and Fc gamma RII on monocytes and granulocytes are cytotoxic trigger molecules for tumor cells. J Immunol. (1987) 139:3536-41.

50. Krutmann J, Kirnbauer R, Kock A, Schwarz T, Schopf E, May LT, et al. Cross-linking Fc receptors on monocytes triggers IL-6 production. Role in anti-CD3-induced T cell activation. J Immunol. (1990) 145:1337-42.

51. Simms HH, Gaither TA, Fries LF, Frank MM. Monokines released during short-term Fc gamma receptor phagocytosis up-regulate polymorphonuclear leukocytes and monocyte-phagocytic function. $J$ Immunol. (1991) 147:265-72.

52. Osuna CE, Lim SY, Kublin JL, Apps R, Chen E, Mota TM, et al. Evidence that CD32a does not mark the HIV-1 latent reservoir. Nature. (2018) 561:E20-8. doi: 10.1038/s41586-018-0495-2

53. Chauhan AK. Human CD4(+) T-cells: a role for low-affinity Fc receptors. Front Immunol. (2016) 7:215. doi: 10.3389/fimmu.2016.00215

54. Canobbio I, Stefanini L, Guidetti GF, Balduini C, Torti M. A new role for FcgammaRIIA in the potentiation of human platelet activation induced by weak stimulation. Cell Signal. (2006) 18:861-70. doi: 10.1016/j.cellsig.2005.07.014

55. Gardiner EE, Karunakaran D, Arthur JF, Mu FT, Powell MS, Baker RI, et al. Dual ITAM-mediated proteolytic pathways for irreversible inactivation of platelet receptors: de-ITAM-izing FcgammaRIIa. Blood. (2008) 111:165-74. doi: 10.1182/blood-2007-04-086983

56. Hibbs ML, Walker ID, Kirszbaum L, Pietersz GA, Deacon NJ, Chambers GW, et al. The murine Fc receptor for immunoglobulin: purification, partial amino acid sequence, and isolation of cDNA clones. Proc Natl Acad Sci USA. (1986) 83:6980-4. doi: 10.1073/pnas.83.18.6980

57. Lewis VA, Koch T, Plutner H, Mellman I. A complementary DNA clone for a macrophage-lymphocyte Fc receptor. Nature. (1986) 324:372-5. doi: $10.1038 / 324372 \mathrm{a} 0$

58. Latour S, Fridman WH, Daeron M. Identification, molecular cloning, biologic properties, and tissue distribution of a novel isoform of murine lowaffinity IgG receptor homologous to human Fc gamma RIIB1. J Immunol. (1996) 157:189-97.

59. Su K, Yang H, Li X, Li X, Gibson AW, Cafardi JM, et al. Expression profile of FcgammaRIIb on leukocytes and its dysregulation in systemic lupus erythematosus. J Immunol. (2007) 178:3272-80. doi: 10.4049/jimmunol.178.5.3272

60. Veri MC, Gorlatov S, Li H, Burke S, Johnson S, Stavenhagen J, et al. Monoclonal antibodies capable of discriminating the human inhibitory Fcgamma-receptor IIB (CD32B) from the activating Fcgamma-receptor IIA (CD32A): biochemical, biological and functional characterization. Immunology. (2007) 121:392-404. doi: 10.1111/j.1365-2567.2007.02588.x
61. Ramsland PA, Farrugia W, Bradford TM, Sardjono CT, Esparon S, Trist $\mathrm{HM}$, et al. Structural basis for Fc gammaRIIa recognition of human IgG and formation of inflammatory signaling complexes. J Immunol. (2011) 187:3208-17. doi: 10.4049/jimmunol.1101467

62. Joshi T, Ganesan LP, Cao X, Tridandapani S. Molecular analysis of expression and function of hFcgammaRIIbl and b2 isoforms in myeloid cells. Mol Immunol. (2006) 43:839-50. doi: 10.1016/j.molimm.2005.06.037

63. Tsang MW, Nagelkerke SQ, Bultink IE, Geissler J, Tanck MW, Tacke CE, et al. Fc-gamma receptor polymorphisms differentially influence susceptibility to systemic lupus erythematosus and lupus nephritis. Rheumatology. (2016) 55:939-48. doi: 10.1093/rheumatology/kev433

64. Sellge G, Barkowsky M, Kramer S, Gebhardt T, Sander LE, Lorentz A, et al. Interferon-gamma regulates growth and controls Fcgamma receptor expression and activation in human intestinal mast cells. BMC Immunol. (2014) 15:27. doi: 10.1186/1471-2172-15-27

65. Burton OT, Epp A, Fanny ME, Miller SJ, Stranks AJ, Teague JE, et al. Tissuespecific expression of the low-affinity IgG receptor, FcgammaRIIb, on human mast cells. Front Immunol. (2018) 9:1244. doi: 10.3389/fimmu.2018.01244

66. Zhao W, Kepley CL, Morel PA, Okumoto LM, Fukuoka Y, Schwartz LB. Fc gamma RIIa, not Fc gamma RIIb, is constitutively and functionally expressed on skin-derived human mast cells. J Immunol. (2006) 177:694-701. doi: 10.4049/jimmunol.177.1.694

67. van der Heijden J, Breunis WB, Geissler J, de Boer M, van den Berg TK, Kuijpers TW. Phenotypic variation in IgG receptors by nonclassical FCGR2C alleles. J Immunol. (2012) 188:1318-24. doi: 10.4049/jimmunol.1003945

68. Xia YC, Schuliga M, Shepherd M, Powell M, Harris T, Langenbach SY, Tan PS, et al. Functional expression of IgG-Fc receptors in human airway smooth muscle cells. Am J Respir Cell Mol Biol. (2011) 44:665-72. doi: 10.1165/rcmb.2009-0371OC

69. Ganesan LP, Kim J, Wu Y, Mohanty S, Phillips GS, Birmingham DJ, et al. FcgammaRIIb on liver sinusoidal endothelium clears small immune complexes. J Immunol. (2012) 189:4981-8. doi: 10.4049/jimmunol.1202017

70. Iwayanagi $\mathrm{Y}$, Igawa $\mathrm{T}$, Maeda A, Haraya $\mathrm{K}$, Wada NA, Shibahara $\mathrm{N}$, et al. Inhibitory FcgammaRIIb-mediated soluble antigen clearance from plasma by a pH-dependent antigen-binding antibody and its enhancement by $\mathrm{Fc}$ engineering. J Immunol. (2015) 195:3198-205. doi: 10.4049/jimmunol.1401470

71. Chu SY, Horton HM, Pong E, Leung IW, Chen H, Nguyen DH, et al. Reduction of total IgE by targeted coengagement of IgE B-cell receptor and FcgammaRIIb with Fc-engineered antibody. J Allergy Clin Immunol. (2012) 129:1102-15. doi: 10.1016/j.jaci.2011.11.029

72. Phillips NE, Parker DC. Fc-dependent inhibition of mouse B cell activation by whole anti-mu antibodies. J Immunol. (1983) 130:602-6.

73. Tiller T, Kofer J, Kreschel C, Busse CE, Riebel S, Wickert S, et al. Development of self-reactive germinal center B cells and plasma cells in autoimmune Fc gammaRIIB-deficient mice. J Exp Med. (2010) 207:2767-78. doi: $10.1084 /$ jem.20100171

74. Nimmerjahn F, Ravetch JV. Fcgamma receptors as regulators of immune responses. Nat Rev Immunol. (2008) 8:34-47. doi: 10.1038/nri2206

75. Baerenwaldt A, Lux A, Danzer H, Spriewald BM, Ullrich E, Heidkamp G, et al. Fcgamma receptor IIB (FcgammaRIIB) maintains humoral tolerance in the human immune system in vivo. Proc Natl Acad Sci USA. (2011) 108:18772-7. doi: 10.1073/pnas.1111810108

76. Daeron M, Lesourne R. Negative signaling in Fc receptor complexes. $A d v$ Immunol. (2006) 89:39-86. doi: 10.1016/S0065-2776(05)89002-9

77. Liu Y, Masuda E, Blank MC, Kirou KA, Gao X, Park MS, et al. Cytokinemediated regulation of activating and inhibitory $\mathrm{Fc}$ gamma receptors in human monocytes. J Leukoc Biol. (2005) 77:767-76. doi: 10.1189/jlb.0904532

78. Espeli M, Smith KG, Clatworthy MR. FcgammaRIIB and autoimmunity. Immunol Rev. (2016) 269:194-211. doi: 10.1111/imr. 12368

79. Hunter S, Indik ZK, Kim MK, Cauley MD, Park JG, Schreiber AD. Inhibition of Fcgamma receptor-mediated phagocytosis by a nonphagocytic Fcgamma receptor. Blood. (1998) 91:1762-8.

80. Malbec O, Fong DC, Turner M, Tybulewicz VL, Cambier JC, Fridman WH, et al. Fc epsilon receptor I-associated lyn-dependent phosphorylation of Fc gamma receptor IIB during negative regulation of mast cell activation. $J$ Immunol. (1998) 160:1647-58. 
81. Bewarder N, Weinrich V, Budde P, Hartmann D, Flaswinkel H, Reth $\mathrm{M}$, et al. In vivo and in vitro specificity of protein tyrosine kinases for immunoglobulin G receptor (FcgammaRII) phosphorylation. Mol Cell Biol. (1996) 16:4735-43. doi: 10.1128/MCB.16.9.4735

82. Lesourne R, Bruhns $\mathrm{P}$, Fridman $\mathrm{WH}$, Daeron $\mathrm{M}$. Insufficient phosphorylation prevents fc gamma RIIB from recruiting the $\mathrm{SH} 2$ domain-containing protein-tyrosine phosphatase SHP-1. J Biol Chem. (2001) 276:6327-36. doi: 10.1074/jbc.M006537200

83. Isnardi I, Lesourne R, Bruhns P, Fridman WH, Cambier JC, Daeron M. Two distinct tyrosine-based motifs enable the inhibitory receptor FcgammaRIIB to cooperatively recruit the inositol phosphatases SHIP1/2 and the adapters Grb2/Grap. J Biol Chem. (2004) 279:51931-8. doi: 10.1074/jbc.M410 261200

84. Isnardi I, Bruhns P, Bismuth G, Fridman WH, Daeron M. The SH2 domain-containing inositol 5-phosphatase SHIP1 is recruited to the intracytoplasmic domain of human FcgammaRIIB and is mandatory for negative regulation of B cell activation. Immunol Lett. (2006) 104:156-65. doi: 10.1016/j.imlet.2005.11.027

85. Aman MJ, Tosello-Trampont AC, Ravichandran K. Fc gamma RIIB1/SHIPmediated inhibitory signaling in B cells involves lipid rafts. J Biol Chem. (2001) 276:46371-8. doi: 10.1074/jbc.M104069200

86. Fong DC, Brauweiler A, Minskoff SA, Bruhns P, Tamir I, Mellman I, et al. Mutational analysis reveals multiple distinct sites within Fc gamma receptor IIB that function in inhibitory signaling. J Immunol. (2000) 165:4453-62. doi: 10.4049/jimmunol.165.8.4453

87. Wang J, Li Z, Xu L, Yang H, Liu W. Transmembrane domain dependent inhibitory function of FcgammaRII. Protein Cell B. (2018) 9:1004-12. doi: 10.1007/s13238-018-0509-8

88. Xiang Z, Cutler AJ, Brownlie RJ, Fairfax K, Lawlor KE, Severinson E, et al. FcgammaRIIb controls bone marrow plasma cell persistence and apoptosis. Nat Immunol. (2007) 8:419-29. doi: 10.1038/ni1440

89. Gast M, Preisinger C, Nimmerjahn F, Huber M. IgG-independent Co-aggregation of FcepsilonRI and FcgammaRIIB Results in LYNand SHIP1-dependent tyrosine phosphorylation of FcgammaRIIB in murine bone marrow-derived mast cells. Front Immunol. (2018) 9:1937. doi: 10.3389/fimmu.2018.01937

90. Lehmann B, Schwab I, Bohm S, Lux A, Biburger M, Nimmerjahn F. FcgammaRIIB: a modulator of cell activation and humoral tolerance. Expert Rev Clin Immunol. (2012) 8:243-54. doi: 10.1586/eci.12.5

91. Malbec O, Daeron M. The mast cell IgG receptors and their roles in tissue inflammation. Immunol Rev. (2007) 217:206-21. doi: 10.1111/j.1600-065X.2007.00510.x

92. Miettinen HM, Matter K, Hunziker W, Rose JK, Mellman I. Fc receptor endocytosis is controlled by a cytoplasmic domain determinant that actively prevents coated pit localization. J Cell Biol. (1992) 116:875-88. doi: $10.1083 /$ jcb.116.4.875

93. Budde P, Bewarder N, Weinrich V, Schulzeck O, Frey J. Tyrosine-containing sequence motifs of the human immunoglobulin $G$ receptors FcRIIb1 and FcRIIb2 essential for endocytosis and regulation of calcium flux in B cells. J Biol Chem. (1994) 269:30636-44.

94. Hunziker W, Fumey C. A di-leucine motif mediates endocytosis and basolateral sorting of macrophage IgG Fc receptors in MDCK cells. EMBO J. (1994) 13:2963-9. doi: 10.1002/j.1460-2075.1994.tb0 6594.x

95. Van Den Herik-Oudijk JG, Westerdaal NA, Henriquez NV, Capel PJ, Van De Winkel IE. Functional analysis of human Fc gamma RII (CD32) isoforms expressed in B lymphocytes. J Immunol. (1994) 152:574-85.

96. Warmerdam PA van den Herik-Oudijk IE, Parren PW, Westerdaal NA, van de Winkel JG, Capel PJ. Interaction of a human Fc gamma RIIb1 (CD32) isoform with murine and human IgG subclasses. Int Immunol. (1993) 5:239-47. doi: 10.1093/intimm/5.3.239

97. Pearse RN, Kawabe T, Bolland S, Guinamard R, Kurosaki T, Ravetch JV. SHIP recruitment attenuates Fc gamma RIIB-induced B cell apoptosis. Immunity. (1999) 10:753-60. doi: 10.1016/S1074-7613(00)80074-6

98. Fakher M, Wu J, Qin D, Szakal A, Tew J. Follicular dendritic cell accessory activity crosses MHC and species barriers. Eur J Immunol. (2001) 31:176-85. doi: 10.1002/1521-4141(200101)31:1<176::AID-IMMU176<3.0.CO;2-H
99. Sukumar S, El Shikh ME, Tew JG, Szakal AK. Ultrastructural study of highly enriched follicular dendritic cells reveals their morphology and the periodicity of immune complex binding. Cell Tissue Res. (2008) 332:89-99. doi: 10.1007/s00441-007-0566-4

100. El Shikh ME, El Sayed RM, Sukumar S, Szakal AK, Tew JG. Activation of B cells by antigens on follicular dendritic cells. Trends Immunol. (2010) 31:205-11. doi: 10.1016/j.it.2010.03.002

101. Cassard L, Jonsson F, Arnaud S, Daeron M. Fcgamma receptors inhibit mouse and human basophil activation. J Immunol. (2012) 189:2995-3006. doi: 10.4049/jimmunol.1200968

102. Cady CT, Powell MS, Harbeck RJ, Giclas PC, Murphy JR, Katial RK, et al. IgG antibodies produced during subcutaneous allergen immunotherapy mediate inhibition of basophil activation via a mechanism involving both FcgammaRIIA and FcgammaRII. Immunol Lett B. (2010) 130:57-65. doi: 10.1016/j.imlet.2009.12.001

103. Wijngaarden S, van de Winkel JG, Jacobs KM, Bijlsma JW, Lafeber FP, van Roon JA. A shift in the balance of inhibitory and activating Fcgamma receptors on monocytes toward the inhibitory Fcgamma receptor IIb is associated with prevention of monocyte activation in rheumatoid arthritis. Arthritis Rheum. (2004) 50:3878-87. doi: 10.1002/art.20672

104. Clynes R, Maizes JS, Guinamard R, Ono M, Takai T, Ravetch JV. Modulation of immune complex-induced inflammation in vivo by the coordinate expression of activation and inhibitory Fc receptors. J Exp Med. (1999) 189:179-85. doi: 10.1084/jem.189.1.179

105. Metes D, Ernst LK, Chambers WH, Sulica A, Herberman RB, Morel PA. Expression of functional CD32 molecules on human NK cells is determined by an allelic polymorphism of the FcgammaRIIC gene. Blood. (1998) 91:2369-80.

106. Breunis WB, van Mirre E, Bruin M, Geissler J, de Boer M, Peters M, et al. Copy number variation of the activating FCGR2C gene predisposes to idiopathic thrombocytopenic purpura. Blood. (2008) 111:1029-38. doi: 10.1182/blood-2007-03-079913

107. Ernst LK, Metes D, Herberman RB, Morel PA. Allelic polymorphisms in the FcgammaRIIC gene can influence its function on normal human natural killer cells. J Mol Med. (2002) 80:248-57. doi: 10.1007/s00109-001-0294-2

108. Li X, Wu J, Ptacek T, Redden DT, Brown EE, Alarcon GS, et al. Allelic-dependent expression of an activating $\mathrm{Fc}$ receptor on B cells enhances humoral immune responses. Sci Transl Med. (2013) 5:216ra175. doi: 10.1126/scitranslmed.3007097

109. Peng X, Li SS, Gilbert PB, Geraghty DE, Katze MG. FCGR2C Polymorphisms associated with HIV-1 vaccine protection are linked to altered gene expression of Fc-gamma receptors in human B cells. PLoS ONE. (2016) 11:e0152425. doi: 10.1371/journal.pone.0152425

110. Warncke M, Calzascia T, Coulot M, Balke N, Touil R, Kolbinger F, et al. Different adaptations of IgG effector function in human and nonhuman primates and implications for therapeutic antibody treatment. J Immunol. (2012) 188:4405-11. doi: 10.4049/jimmunol.1200090

111. Wines BD, Vanderven HA, Esparon SE, Kristensen AB, Kent SJ, Hogarth PM. Dimeric FcgammaR ectodomains as probes of the Fc receptor function of anti-influenza virus Ig. J Immunol G. (2016) 197:1507-16. doi: 10.4049/jimmunol.1502551

112. Lux A, Yu X, Scanlan CN, Nimmerjahn F. Impact of immune complex size and glycosylation on IgG binding to human FcgammaRs. J Immunol. (2013) 190:4315-23. doi: 10.4049/jimmunol.1200501

113. Wines BD, Tan CW, Duncan E, McRae S, Baker RI, Andrews RK, et al. Dimeric FcgammaR ectodomains detect pathogenic anti-platelet factor 4-heparin antibodies in heparin-induced thromobocytopenia. J Thromb Haemost. (2018) 16:2520-25. doi: 10.1111/jth.14306

114. Bournazos S, Hart SP, Chamberlain LH, Glennie MJ, Dransfield I. Association of FcgammaRIIa (CD32a) with lipid rafts regulates ligand binding activity. J Immunol. (2009) 182:8026-36. doi: 10.4049/jimmunol.0900107

115. Kanters D, ten Hove W, Luijk B, van Aalst C, Schweizer RC, Lammers JW, et al. Expression of activated Fc gamma RII discriminates between multiple granulocyte-priming phenotypes in peripheral blood of allergic asthmatic subjects. J Allergy Clin Immunol. (2007) 120:1073-81. doi: 10.1016/j.jaci.2007.06.021 
116. Graziano RF, Looney RJ, Shen L, Fanger MW. Fc gamma R-mediated killing by eosinophils. J Immunol. (1989) 142:230-5.

117. Nagarajan S, Venkiteswaran K, Anderson M, Sayed U, Zhu C, Selvaraj P. Cell-specific, activation-dependent regulation of neutrophil CD32A ligandbinding function. Blood. (2000) 95:1069-77.

118. Maxwell KF, Powell MS, Hulett MD, Barton PA, McKenzie IF, Garrett TP, et al. Crystal structure of the human leukocyte Fc receptor, Fc gammaRIIa. Nat Struct Biol. (1999) 6:437-42. doi: 10.1038/8241

119. Brandsma AM, Schwartz SL, Wester MJ, Valley CC, Blezer GL A, Vidarsson $\mathrm{G}$, et al. Mechanisms of inside-out signaling of the high-affinity IgG receptor FcgammaR. Sci Signal I. (2018) 11:540. doi: 10.1126/scisignal.aaq0891

120. Lu J, Sun PD. Structural mechanism of high affinity FcgammaRI recognition of immunoglobulin. Immunol Rev G. (2015) 268:192-200. doi: 10.1111/imr.12346

121. Radaev S, Sun P. Recognition of immunoglobulins by Fcgamma receptors. Mol Immunol. (2002) 38:1073-83. doi: 10.1016/S0161-5890(02) 00036-6

122. Sondermann P, Oosthuizen V. X-ray crystallographic studies of IgGFc gamma receptor interactions. Biochem Soc Trans. (2002) 30:481-6. doi: 10.1042/bst0300481

123. Mimoto F, Igawa $T$, Kuramochi $T$, Katada H, Kadono S, Kamikawa $\mathrm{T}$, et al. Novel asymmetrically engineered antibody Fc variant with superior FcgammaR binding affinity and specificity compared with afucosylated Fc variant. MAbs. (2013) 5:229-36. doi: 10.4161/mabs. 23452

124. Caaveiro JM, Kiyoshi M, Tsumoto K. Structural analysis of Fc/FcgammaR complexes: a blueprint for antibody design. Immunol Rev. (2015) 268:20121. doi: 10.1111/imr.12365

125. Warnerdanm OAM, van de Winkel J, Gosselin EJ, Capel JG. Molecular basis for a polymorphism of human Fc gamma receptor II (CD32). J Exp Med. (1990) 172:19-25. doi: 10.1084/jem.172.1.19

126. Norris CF, Pricop L, Millard SS, Taylor SM, Surrey S, Schwartz E, et al. A naturally occurring mutation in Fc gamma RIIA: a Q to K127 change confers unique IgG binding properties to the R131 allelic form of the receptor. Blood. (1998) 91:656-62.

127. Flinsenberg TW, Janssen WJ, Herczenik E, Boross P, Nederend M, Jongeneel LH, et al. A novel FcgammaRIIa Q27W gene variant is associated with common variable immune deficiency through defective FcgammaRIIa downstream signaling. Clin Immunol. (2014) 155:108-17. doi: 10.1016/j.clim.2014.09.006

128. Warmerdam PA van de Winkel JG, Vlug A, Westerdaal NA, Capel PJ. A single amino acid in the second Ig-like domain of the human Fc gamma receptor II is critical for human IgG2 binding. J Immunol. (1991) 147:1338-43.

129. Parren PW, Warmerdam PA, Boeije LC, Arts J, Westerdaal NA, Vlug A, et al. On the interaction of IgG subclasses with the low affinity Fc gamma RIIa (CD32) on human monocytes, neutrophils, and platelets. Analysis of a functional polymorphism to human IgG2. J Clin Invest. (1992) 90:1537-46. doi: 10.1172/JCI116022

130. Kuo HC, Hsu YW, Wu MS, Woon PY, Wong HS, Tsai LJ, et al. FCGR2A promoter methylation and risks for intravenous immunoglobulin treatment responses in kawasaki disease. Mediators Inflamm. (2015) 2015:564625. doi: 10.1155/2015/564625

131. Su K, Wu J, Edberg JC, Li X, Ferguson P, Cooper GS, et al. A promoter haplotype of the immunoreceptor tyrosine-based inhibitory motif-bearing FcgammaRIIb alters receptor expression and associates with autoimmunity. I. Regulatory FCGR2B polymorphisms and their association with systemic lupus erythematosus. J Immunol. (2004) 172:7186-91. doi: 10.4049/jimmunol.172.11.7186

132. Willcocks LC, Carr EJ, Niederer HA, Rayner TF, Williams TN, Yang W, et al. A defunctioning polymorphism in FCGR2B is associated with protection against malaria but susceptibility to systemic lupus erythematosus. Proc Natl Acad Sci USA. (2010) 107:7881-5. doi: 10.1073/pnas.0915133107

133. Floto RA, Clatworthy MR, Heilbronn KR, Rosner DR, MacAry PA, Rankin A, et al. Loss of function of a lupus-associated FcgammaRIIb polymorphism through exclusion from lipid rafts. Nat Med. (2005) 11:1056-8. doi: $10.1038 / \mathrm{nm} 1288$
134. Kyogoku C, Dijstelbloem HM, Tsuchiya N, Hatta Y, Kato H, Yamaguchi A, et al. Fcgamma receptor gene polymorphisms in Japanese patients with systemic lupus erythematosus: contribution of FCGR2B to genetic susceptibility. Arthritis Rheum. (2002) 46:1242-54. doi: 10.1002/art.10257

135. Li X, Wu J, Carter RH, Edberg JC, Su K, Cooper GS, et al. A novel polymorphism in the Fcgamma receptor IIB (CD32B) transmembrane region alters receptor signaling. Arthritis Rheum. (2003) 48:3242-52. doi: 10.1002/art.11313

136. Kono H, Kyogoku C, Suzuki T, Tsuchiya N, Honda H, Yamamoto K, et al. FcgammaRIIB Ile232Thr transmembrane polymorphism associated with human systemic lupus erythematosus decreases affinity to lipid rafts and attenuates inhibitory effects on B cell receptor signaling. Hum Mol Genet. (2005) 14:2881-92. doi: 10.1093/hmg/ddi320

137. Xu L, Xia M, Guo J, Sun X, Li H, Xu C, et al. Impairment on the lateral mobility induced by structural changes underlies the functional deficiency of the lupus-associated polymorphism FcgammaRIIB-T232. J Exp Med. (2016) 213:2707-27. doi: 10.1084/jem.20160528

138. Li SS, Gilbert PB, Tomaras GD, Kijak G, Ferrari G, Thomas R, et al. FCGR2C polymorphisms associate with HIV-1 vaccine protection in RV144 trial. J Clin Invest. (2014) 124:3879-90. doi: 10.1172/JCI75539

139. Kaifu T, Nakamura A. Polymorphisms of immunoglobulin receptors and the effects on clinical outcome in cancer immunotherapy and other immune diseases: a general review. Int Immunol. (2017) 29:319-325. doi: 10.1093/intimm/dxx041

140. Li X, Gibson AW, Kimberly RP. Human FcR polymorphism and disease. Curr Top Microbiol Immunol. (2014) 382:275-302. doi: 10.1007/978-3-319-07911-0_13

141. Li X, Kimberly RP. Targeting the Fc receptor in autoimmune disease. Expert Opin Ther Targets. (2014) 18:335-50. doi: 10.1517/14728222.2014.877891

142. Nakamura A, Kubo T, Takai T. Fc receptor targeting in the treatment of allergy, autoimmune diseases and cancer. Adv Exp Med Biol. (2008) 640:220-33. doi: 10.1007/978-0-387-09789-3_17

143. Willcocks LC, Smith KG, Clatworthy MR. Low-affinity Fcgamma receptors, autoimmunity and infection. Expert Rev Mol Med. (2009) 11:e24. doi: $10.1017 /$ s1462399409001161

144. Rodriguez ME, van der Pol WL, Sanders LA, van de Winkel JG. Crucial role of FcgammaRIIa (CD32) in assessment of functional anti-Streptococcus pneumoniae antibody activity in human sera. J Infect Dis. (1999) 179:423-33. doi: $10.1086 / 314603$

145. Yuan FF, Wong M, Pererva N, Keating J, Davis AR, Bryant JA, et al. FcgammaRIIA polymorphisms in Streptococcus pneumoniae infection. Immunol Cell Biol. (2003) 81:192-5. doi: 10.1046/j.1440-1711.2003.01158.x

146. Pathan N, Faust SN, Levin M. Pathophysiology of meningococcal meningitis and septicaemia. Arch Dis Child. (2003) 88:601-7. doi: 10.1136/adc.88.7.601

147. Nicu EA, Van der Velden U, Everts V, Van Winkelhoff AJ, Roos D, Loos BG. Hyper-reactive PMNs in FcgammaRIIa $131 \mathrm{H} / \mathrm{H}$ genotype periodontitis patients. J Clin Periodontol. (2007) 34:938-45. doi: 10.1111/j.1600-051X.2007.01136.x

148. van Egmond M, Vidarsson G, Bakema JE. Cross-talk between pathogen recognizing Toll-like receptors and immunoglobulin Fc receptors in immunity. Immunol Rev. (2015) 268:311-27. doi: 10.1111/imr.12333

149. Wenink MH, Santegoets KC, Roelofs MF, Huijbens R, Koenen HJ, van Beek $\mathrm{R}$, et al. The inhibitory Fc gamma IIb receptor dampens TLR4-mediated immune responses and is selectively up-regulated on dendritic cells from rheumatoid arthritis patients with quiescent disease. J Immunol. (2009) 183:4509-20. doi: 10.4049/jimmunol.0900153

150. Bakema JE, Tuk CW, van Vliet SJ, Bruijns SC, Vos JB, Letsiou S, et al. Antibody-opsonized bacteria evoke an inflammatory dendritic cell phenotype and polyfunctional Th cells by cross-talk between TLRs and FcRs. J Immunol. (2015) 194:1856-66. doi: 10.4049/jimmunol.1303126

151. French MA, Tanaskovic S, Law MG, Lim A, Fernandez S, Ward LD, et al. Vaccine-induced IgG2 anti-HIV p24 is associated with control of HIV in patients with a 'high-affinity' FcgammaRIIa genotype. AIDS. (2010) 24:198390. doi: 10.1097/QAD.0b013e32833c1ce0

152. Forthal DN, Gabriel EE, Wang A, Landucci G, Phan TB. Association of Fcgamma receptor IIIa genotype with the rate of HIV infection after gp120 vaccination. Blood. (2012) 120:2836-42. doi: 10.1182/blood-2012-05-431361 
153. Sips M, Krykbaeva M, Diefenbach TJ, Ghebremichael M, Bowman BA, Dugast AS, et al. Fc receptor-mediated phagocytosis in tissues as a potent mechanism for preventive and therapeutic HIV vaccine strategies. Mucosal Immunol. (2016) 9:1584-95. doi: 10.1038/mi.2016.12

154. Brouwer KC, Lal AA, Mirel LB, Otieno J, Ayisi J, Van Eijk AM, et al. Polymorphism of Fc receptor IIa for immunoglobulin $\mathrm{G}$ is associated with placental malaria in HIV-1-positive women in western Kenya. J Infect Dis. (2004) 190:1192-8. doi: 10.1086/422850

155. Groux H, Gysin J. Opsonization as an effector mechanism in human protection against asexual blood stages of Plasmodium falciparum: functional role of IgG subclasses. Res Immunol. (1990) 141:529-42. doi: 10.1016/0923-2494(90)90021-P

156. Brouwer KC, Lal RB, Mirel LB, Yang C, van Eijk AM, Ayisi J, et al. Polymorphism of $\mathrm{FC}$ receptor IIa for IgG in infants is associated with susceptibility to perinatal HIV-1 infection. AIDS. (2004) 18:1187-94. doi: 10.1097/00002030-200405210-00012

157. Descours B, Petitjean G, Lopez-Zaragoza JL, Bruel T, Raffel R, Psomas C, et al. CD32a is a marker of a CD4 T-cell HIV reservoir harbouring replicationcompetent proviruses. Nature (2017) 543:564-7. doi: 10.1038/nature21710

158. Perez L, Anderson J, Chipman J, Thorkelson A, Chun TW, Moir S, et al. Conflicting evidence for HIV enrichment in CD32(+) CD4 T cells. Nature. (2018) 561:E9-16. doi: 10.1038/s41586-018-0493-4

159. Abdel-Mohsen M, Kuri-Cervantes L, Grau-Exposito J, Spivak AM, Nell RA, Tomescu C, et al. CD32 is expressed on cells with transcriptionally active HIV but does not enrich for HIV DNA in resting T cells. Sci Transl Med. (2018) 10:437. doi: 10.1126/scitranslmed.aar6759

160. Gan ES, Ting DH, Chan KR. The mechanistic role of antibodies to dengue virus in protection and disease pathogenesis. Expert Rev Anti Infect Ther. (2017) 15:111-9. doi: 10.1080/14787210.2017.1254550

161. Chan KR, Zhang SL, Tan HC, Chan YK, Chow A, Lim AP, et al. Ligation of Fc gamma receptor IIB inhibits antibody-dependent enhancement of dengue virus infection. Proc Natl Acad Sci USA. (2011) 108:12479-84. doi: 10.1073/pnas.1106568108

162. Boonnak K, Slike BM, Donofrio GC, Marovich MA. Human FcgammaRII cytoplasmic domains differentially influence antibodymediated dengue virus infection. J Immunol. (2013) 190:5659-65. doi: 10.4049/jimmunol.1203052

163. Clatworthy MR, Smith KG. FcgammaRIIb balances efficient pathogen clearance and the cytokine-mediated consequences of sepsis. J Exp Med. (2004) 199:717-23. doi: 10.1084/jem.20032197

164. Brownlie RJ, Lawlor KE, Niederer HA, Cutler AJ, Xiang Z, Clatworthy $\mathrm{MR}$, et al. Distinct cell-specific control of autoimmunity and infection by FcgammaRIIb. J Exp Med. (2008) 205:883-95. doi: 10.1084/jem.20072565

165. Bave U, Magnusson M, Eloranta ML, Perers A, Alm GV, Ronnblom L. Fc gamma RIIa is expressed on natural IFN-alpha-producing cells (plasmacytoid dendritic cells) and is required for the IFN-alpha production induced by apoptotic cells combined with lupus Ig. J Immunol G. (2003) 171:3296-302. doi: 10.4049/jimmunol.171.6.3296

166. $\mathrm{Yu} \mathrm{X}$, Lazarus AH. Targeting FcgammaRs to treat antibodydependent autoimmunity. Autoimmun Rev. (2016) 15:510-2. doi: 10.1016/j.autrev.2016.02.006

167. Smith KG, Clatworthy MR. FcgammaRIIB in autoimmunity and infection: evolutionary and therapeutic implications. Nat Rev Immunol. (2010) 10:32843. doi: $10.1038 /$ nri2762

168. van der Pol WL, van den Berg LH, Scheepers RH van der Bom JG, van Doorn PA, van Koningsveld $\mathrm{R}$, et al. IgG receptor IIa alleles determine susceptibility and severity of Guillain-Barre syndrome. Neurology. (2000) 54:1661-5. doi: 10.1212/WNL.54.8.1661

169. Khor CC, Davila S, Breunis WB, Lee YC, Shimizu C, Wright VJ, et al. Genome-wide association study identifies FCGR2A as a susceptibility locus for Kawasaki disease. Nat Genet. (2011) 43:1241-6. doi: 10.1038/ ng.981

170. Asano K, Matsushita T, Umeno J, Hosono N, Takahashi A, Kawaguchi T, et al. A genome-wide association study identifies three new susceptibility loci for ulcerative colitis in the Japanese population. Nat Genet. (2009) 41:1325-9. doi: $10.1038 /$ ng.482

171. Raaz D, Herrmann M, Ekici AB, Klinghammer L, Lausen B, Voll RE, et al. FcgammaRIIa genotype is associated with acute coronary syndromes as first manifestation of coronary artery disease. Atherosclerosis. (2009) 205:512-6. doi: 10.1016/j.atherosclerosis.2009.01.013

172. Karassa FB, Bijl M, Davies KA, Kallenberg CG, Khamashta MA, Manger K, et al. Role of the Fcgamma receptor IIA polymorphism in the antiphospholipid syndrome: an international meta-analysis. Arthritis Rheum. (2003) 48:19308. doi: 10.1002/art.11059

173. Raaz-Schrauder D, Ekici AB, Munoz LE, Klinghammer L, Voll RE, Leusen $\mathrm{JH}$ et al. Patients with unstable angina pectoris show an increased frequency of the Fc gamma RIIa R131 allele. Autoimmunity. (2012) 45:556-64. doi: 10.3109/08916934.2012.682665

174. van der Pol WL, Jansen MD, Kuks JB, de Baets M, Leppers-van de Straat, Wokke JH, et al. Association of the Fc gamma receptor IIA-R/R131 genotype with myasthenia gravis in Dutch patients. J Neuroimmunol. (2003) 144:1437. doi: 10.1016/j.jneuroim.2003.08.043

175. Mathsson L, Lampa J, Mullazehi M, Ronnelid J. Immune complexes from rheumatoid arthritis synovial fluid induce FcgammaRIIa dependent and rheumatoid factor correlated production of tumour necrosis factor-alpha by peripheral blood mononuclear cells. Arthritis Res Ther. (2006) 8:R64. doi: $10.1186 / \operatorname{ar} 1926$

176. Ronnelid J, Tejde A, Mathsson L, Nilsson-Ekdahl K, Nilsson B. Immune complexes from SLE sera induce IL10 production from normal peripheral blood mononuclear cells by an FcgammaRII dependent mechanism: implications for a possible vicious cycle maintaining B cell hyperactivity in SLE. Ann Rheum Dis. (2003) 62:37-42. doi: 10.1136/ard.62.1.37

177. Chang LS, Lo MH, Li SC, Yang MY, Hsieh KS, Kuo HC. The effect of FcgammaRIIA and FcgammaRIIB on coronary artery lesion formation and intravenous immunoglobulin treatment responses in children with Kawasaki disease. Oncotarget. (2017) 8:2044-52. doi: 10.18632/oncotarget.13489

178. Stewart-Akers AM, Cunningham A, Wasko MC, Morel PA. Fc gamma R expression on NK cells influences disease severity in rheumatoid arthritis. Genes Immun. (2004) 5:521-9. doi: 10.1038/sj.gene.6364121

179. Blank MC, Stefanescu RN, Masuda E, Marti F, King PD, Redecha $\mathrm{PB}$, et al. Decreased transcription of the human FCGR2B gene mediated by the $-343 \mathrm{G} / \mathrm{C}$ promoter polymorphism and association with systemic lupus erythematosus. Hum Genet. (2005) 117:220-7. doi: 10.1007/s00439-005-1302-3

180. Radstake TR, Franke B, Wenink MH, Nabbe KC, Coenen MJ, Welsing $\mathrm{P}$, et al. The functional variant of the inhibitory Fcgamma receptor IIb $(\mathrm{CD} 32 \mathrm{~B})$ is associated with the rate of radiologic joint damage and dendritic cell function in rheumatoid arthritis. Arthritis Rheum. (2006) 54:3828-37. doi: 10.1002/art.22275

181. Xu L, Li G, Wang J, Fan Y, Wan Z, Zhang S, et al. Through an ITIMindependent mechanism the FcgammaRIIB blocks B cell activation by disrupting the colocalized microclustering of the B cell receptor and CD19. J Immunol. (2014) 192:5179-91. doi: 10.4049/jimmunol.1400101

182. Cassard L, Cohen-Solal JF, Fournier EM, Camilleri-Broet S, Spatz A, Chouaib $\mathrm{S}$, et al. Selective expression of inhibitory Fcgamma receptor by metastatic melanoma impairs tumor susceptibility to IgG-dependent cellular response. Int J Cancer. (2008) 123:2832-9. doi: 10.1002/ijc.23870

183. Gul N, van Egmond M. Antibody-dependent phagocytosis of tumor cells by macrophages: a potent effector mechanism of monoclonal antibody therapy of cancer. Cancer Res. (2015) 75:5008-13. doi: 10.1158/0008-5472.CAN-15-1330

184. Weng WK, Levy R. Two immunoglobulin G fragment C receptor polymorphisms independently predict response to rituximab in patients with follicular lymphoma. J Clin Oncol. (2003) 21:3940-7. doi: 10.1200/JCO.2003.05.013

185. Bibeau F, Lopez-Crapez E, Di Fiore F, Thezenas S, Ychou M, Blanchard F, et al. Impact of Fc \{gamma\}RIIa-Fc \{gamma\}RIIIa polymorphisms and KRAS mutations on the clinical outcome of patients with metastatic colorectal cancer treated with cetuximab plus irinotecan. J Clin Oncol. (2009) 27:11229. doi: 10.1200/JCO.2008.18.0463

186. Vaughan AT, Chan CH, Klein C, Glennie MJ, Beers SA, Cragg MS. Activatory and inhibitory Fcgamma receptors augment rituximab-mediated internalization of CD20 independent of signaling via the cytoplasmic domain. J Biol Chem. (2015) 290:5424-37. doi: 10.1074/jbc.M114.593806

187. Pietersz GA, Mottram PL van de Velde NC, Sardjono CT, Esparon S, Ramsland PA, et al. Inhibition of destructive autoimmune arthritis in 
FcgammaRIIa transgenic mice by small chemical entities. Immunol Cell Biol. (2009) 87:3-12. doi: 10.1038/icb.2008.82

188. Boonyarattanakalin S, Martin SE, Sun Q, Peterson BR. A synthetic mimic of human Fc receptors: defined chemical modification of cell surfaces enables efficient endocytic uptake of human immunoglobulin-G. J Am Chem Soc. (2006) 128:11463-70. doi: 10.1021/ja062377w

189. Belostocki K, Park MS, Redecha PB, Masuda E, Salmon JE, Pricop L. FcgammaRIIa is a target for modulation by TNFalpha in human neutrophils. Clin Immunol. (2005) 117:78-86. doi: 10.1016/j.clim.2005. 07.001

190. Chu SY, Yeter K, Kotha R, Pong E, Miranda Y, Phung S, et al. Suppression of rheumatoid arthritis B cells by XmAb5871, an anti-CD19 antibody that coengages $B$ cell antigen receptor complex and Fcgamma receptor IIb inhibitory receptor. Arthritis Rheumatol. (2014) 66:1153-64. doi: $10.1002 /$ art.38334

191. Horton HM, Chu SY, Ortiz EC, Pong E, Cemerski S, Leung IW, et al. Antibody-mediated coengagement of FcgammaRIIb and B cell receptor complex suppresses humoral immunity in systemic lupus erythematosus. J Immunol. (2011) 186:4223-33. doi: 10.4049/jimmunol. 1003412

192. Ellsworth JL, Hamacher N, Harder B, Bannink K, Bukowski TR, ByrnesBlake K, et al. Recombinant soluble human FcgammaR1A (CD64A) reduces inflammation in murine collagen-induced arthritis. J Immunol. (2009) 182:7272-9. doi: 10.4049/jimmunol.0803497
193. Magnusson SE, Andren M, Nilsson KE, Sondermann P, Jacob U, Kleinau S. Amelioration of collagen-induced arthritis by human recombinant soluble FcgammaRIIb. Clin Immunol. (2008) 127:225-33. doi: 10.1016/j.clim.2008.02.002

194. Konstaninova TS, Leonidovna IV, Hellmann A, Kyrcz-Krzemien S, Tillmanns S, Sondermann P, et al. Interim results from a phase Ib/IIa clinical trial with the soluble Fc-gamma IIb receptor SM101 for the treatment of primary immune thrombocytopenia. Blood. (2012) 120:3388.

195. Tillmanns S, Kolligs C, D'Cruz DP, Doria A, Hachulla E, Voll RE, et al. SM101, a novel recombinant, soluble, human FcgIIB receptor, in the treatment of systemic lupus erythematosus: results of a doubleblind, placebocontrolled multicenter study. Am Coll Rheumatol. (2014) 66:S1238.

Conflict of Interest Statement: The authors declare that the research was conducted in the absence of any commercial or financial relationships that could be construed as a potential conflict of interest.

Copyright (c) 2019 Anania, Chenoweth, Wines and Hogarth. This is an open-access article distributed under the terms of the Creative Commons Attribution License (CC $B Y)$. The use, distribution or reproduction in other forums is permitted, provided the original author(s) and the copyright owner(s) are credited and that the original publication in this journal is cited, in accordance with accepted academic practice. No use, distribution or reproduction is permitted which does not comply with these terms. 